\title{
1993 EFFLUENT AND ENVIRONMENTAL MONITORING REPORT FOR THE BETTIS ATOMIC POWER LABORATORY PITTSBURGH SITE
}

\author{
PREPARED FOR THE U.S. DEPARTMENT OF ENERGY BY \\ WESTINGHOUSE ELECTRIC CORPORATION \\ WEST MIFFLIN, PENNSYLVANIA 15122-0079
}

VENDOR CONTRACT NUMBER: DE-AC11-93PN38195

DOCUMENT NUMBER: WAPD-RC/E(EE)-3300 $\checkmark$

\section{DISCLAIMER}

This report was prepared as an account of work sponsored by an agency of the United States Government. Neither the United States Government nor any agency thereof, nor any of their employees, makes any warranty, express or implied, or assumes any legal liability or responsibility for the accuracy, completeness, or usefulness of any information, apparatus, product, or process disclosed, or represents that its use would not infringe privately owned rights. Reference herein to any specific commercial product, process, or service by trade name, trademark, manufacturer, or otherwise does not necessarily constitute or imply its endorsement, recommendation, or favoring by the United States Government or any agency thereof. The views and opinions of authors expressed herein do not necessarily state or reflect those of the United States Government or any agency thereof. 


\section{DISCLAIMER}

Portions of this document may be illegible in electronic image products. Images are produced from the best available original document. 


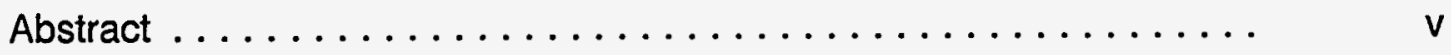

Summary $\ldots \ldots \ldots \ldots \ldots \ldots \ldots \ldots \ldots \ldots \ldots \ldots \ldots \ldots \ldots \ldots$

Introduction $\ldots \ldots \ldots \ldots \ldots \ldots \ldots \ldots \ldots \ldots \ldots \ldots \ldots \ldots, g$

Environmental Monitoring $\ldots \ldots \ldots \ldots \ldots \ldots \ldots \ldots \ldots \ldots \ldots$

A. Liquid Effluents ......................... 14

Sources and Treatment ..................... 14

Effluent (Liquid) Monitoring . . . . . . . . . . . . . . . . 14

Liquid Analyses . ........................ 16

Liquid Monitoring Results and Conclusions ............ 17

B. Ground Water $\ldots \ldots \ldots \ldots \ldots \ldots \ldots \ldots \ldots \ldots \ldots \ldots \ldots \ldots \ldots$

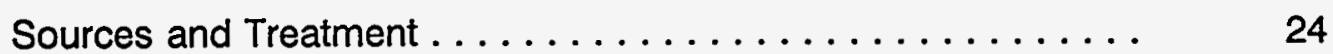

Ground Water Monitoring .................... 24

Ground Water Monitoring Results and Conclusions ........ 24

C. Airborne Effluents $\ldots \ldots \ldots \ldots \ldots \ldots \ldots \ldots \ldots \ldots \ldots \ldots \ldots$

Sources and Treatment .................... 31

Airborne Monitoring $\ldots \ldots \ldots \ldots \ldots \ldots \ldots \ldots \ldots \ldots \ldots \ldots \ldots$

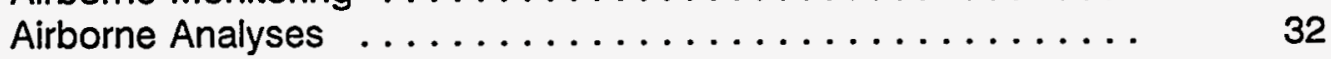

Airborne Monitoring Results and Conclusions .......... 33

D. Stream Sediment, Soil and Vegetation ............. 36

Sources .......................... 36

Sediment, Soil and Vegetation Monitoring $\ldots \ldots \ldots \ldots \ldots \ldots . \quad 36$

Sediment, Soil and Vegetation Analyses ............ 38

Sediment, Soil and Vegetation Monitoring

Results and Conclusions . . . . . . . $38 \ldots \ldots \ldots \ldots .$.

E. Radiation Monitoring $\ldots \ldots \ldots \ldots \ldots \ldots \ldots \ldots \ldots \ldots \ldots$

Radiation Sources $\ldots \ldots \ldots \ldots \ldots \ldots \ldots \ldots \ldots \ldots \ldots$

Radiation Monitoring . . . . . . . . . 43

Radiation Analyses ...................... 45

Radiation Monitoring Results and Conclusions .......... 45

Bull Run Stream/West Mifflin Park Survey ............ 45

F. Control of Chemical and Hazardous Wastes $\ldots \ldots \ldots \ldots \ldots$ 4 47

Origin $\ldots \ldots \ldots \ldots \ldots \ldots \ldots \ldots \ldots \ldots \ldots \ldots \ldots \ldots \ldots \ldots$

Control Program ....................... 47

Treatment and Disposal $\ldots \ldots \ldots \ldots \ldots \ldots \ldots \ldots \ldots$ 
G. Control of Radioactive Waste Materials $\ldots \ldots \ldots \ldots \ldots$

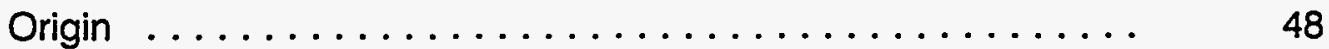

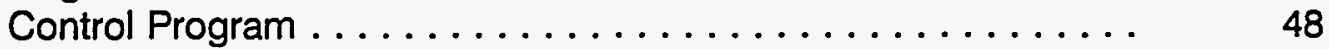

Disposal ........................ 48

H. Environmental and Effluent Monitoring

Quality Assurance ...................... 48

I. Assessment of Risk to Chemical Residues . . . . . . . . . . . . . 49

J. Assessment of Radiation Dose-to-Man $\ldots \ldots \ldots \ldots \ldots \ldots$

K. Environmental Permits $\ldots \ldots \ldots \ldots \ldots \ldots \ldots \ldots \ldots \ldots \ldots \ldots$

References ........................... 54

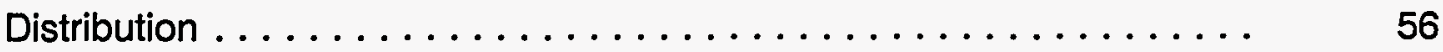

\section{APPENDICES}

Title

Appendix A

Radioanalytical Quality Assurance Results USEPA CrossCheck, CY 1993

Appendix B

Radioanalytical Quality Assurance Results USDOE/EML Cross-Check, CY 1993

Appendix C

Summary of Surface Water Quality Control Data, CY 1993

Appendix D

Environmental Permits

Appendix $\mathbf{E}$

List of Acronyms 
Table 1 Radiological Environmental Monitoring Program . . . . . . . . 5

Table 2 Non-Radiological Environmental Monitoring Program . . . . . . 7

Table 3 Generalized Section of Rock Strata Beneath

the Bettis Laboratory . . . . . . . . . . . . . . . . 12

Table 4 Liquid Effluent Quarterly and Annual Radioactivity

Analysis, CY $1993 \ldots \ldots \ldots \ldots \ldots \ldots \ldots \ldots$

Table 5 Summary of Bimonthly and Quarterly Influent and

Effluent Water Quality Analyses, CY 1993 . . . . . . . . . . . 19

Table $6 \quad$ Annual Influent and Effluent Water Quality Analyses, CY 1993 . . 21

Table 7 Summary of Spring and Surface Water Radioactivity

Results, CY $1993^{\circ} \ldots \ldots \ldots \ldots \ldots \ldots$

Table $8 \quad$ Summary of Ground Water Radioactivity Results, CY $1993 \ldots 27$

Table 9 Summary of Radioactivity in Airborne Effluents,

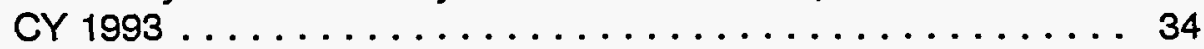

Table $10 \quad$ Stream Sediment Radioactivity Analyses, CY $1993 \ldots \ldots$. . . . 39

Table 11 Stream Vegetation Radioactivity

Analyses, CY 1993 ...................... 40

Table 12 Vegetation Radioactivity Analyses, CY $1993 \ldots \ldots \ldots \ldots \ldots$

Table 13 Environmental Radiation Measurements in the Vicinity of the Bettis Laboratory, CY 1993 . . . . . . . . . . . 46

Table 14 Summary of Calculated Radiation Dose-to-Man from

Bettis Laboratory Operations, CY 1993 . . . . . . . . . . . . 52

\section{LIST OF FIGURES}

Figure 1 Relationship of Bettis Site to Surrounding Communities . . . . 10

Figure 2 Liquid Monitoring Stations . . . . . . . . . . . . 15

Figure $3 \quad$ Locations of Wells and Springs . . . . . . . . . . . 25

Figure 4 Sediment and Vegetation Monitoring Locations . . . . . . . 37

Figure 5 Environmental Dosimeter Locations . . . . . . . . . . . . 44 


\begin{abstract}
The results of the radiological and non-radiological environmental monitoring programs for 1993 at the Bettis-Pittsburgh Site are presented. The results obtained from the monitoring programs demonstrate that the existing procedures ensured that environmental releases during 1993 were in accordance with applicable Federal and State regulations. Evaluation of the environmental data indicates that the current operations at the Site continue to have no adverse effect on the quality of the environment. A conservative assessment of radiation exposure to the general public as a result of Site operations demonstrated that the dose received by any member of the public was well below the most restrictive dose limits established by the U.S. Environmental Protection Agency and the U.S. Department of Energy.
\end{abstract}




\section{EFFLUENT AND ENVIRONMENTAL MONITORING REPORT FOR THE BETTIS ATOMIC POWER LABORATORY-PITTSBURGH SITE}

\section{SUMMARY}

The results of the radiological and non-radiological environmental monitoring programs for the Bettis Atomic Power Laboratory-Pittsburgh Site are summarized below. During 1993 Bettis remained in compliance with applicable regulations governing use, emission and disposal of solid, liquid and gaseous materials. Current operations at the Site did not result in any significant release of radioactivity or hazardous materials to the environment. Tables 1 and 2 summarize the environmental monitoring programs.

\section{LIQUID EFFLUENTS}

\section{Liquid Release (Other than to Sanitary Sewer)}

Approximately $8.6 \times 10^{7}$ gallons of water were released to the environment via the Northeast Area and Bull Run streams. No radioactivity attributable to operations at the Bettis site was detected in any of the environmental samples of these releases. Radioactivity concentrations were either below minimum detection levels or were typical of background levels in city water and precipitation.

Monitoring data for chemical constituents demonstrated no significant impact on the water quality from the effluents. These results continue to demonstrate compliance with U. S. Department of Energy (DOE) standards and the Site's National Pollutant Discharge Elimination System (NPDES) permit.

\section{SANITARY SEWER DISCHARGES}

All sanitary effluents were discharged to a West Mifflin, Pennsylvania sewage treatment facility. No radioactivity attributable to operations of the Site was detected in any of the environmental samples of sanitary effluent.

All wastes discharged to the sanitary system were in compliance with applicable regulations.

\section{GROUND WATER EFFLUENTS}

Analysis of water from natural springs, collected on-site and off-site, did not detect any radioactivity in excess of natural background levels.

Analysis of the vast majority of water from five water-bearing zones beneath the site did not detect any radioactivity in excess of natural background. A small area of perched water contains very low levels of Strontium-90 and a few well water samples show low levels of natural uranium. The maximum concentration of radioactivity is less than $2 \%$ of the limits of 10CFR20 for the specific radionuclides in water in unrestricted areas.

Analysis of the seepage runoff from the Inactive Waste Site (IWS) shows the presence of low levels of natural uranium and Strontium-90. The concentrations of radionuclides detected were well below their 10CFR20 limits for water in unrestricted areas.

The results of the majority of the ground water analyses for a variety of chemicals were less than minimum detectable levels; some analyses did indicate the presence of volatile organic compounds (NOCs), primarily tetrachloroethylene (perchloroethylene, PCE), which are associated with past degreasing operations. The presence of these chemicals is not due to current laboratory operations. 


\section{STREAM SEDIMENTS AND VEGETATION}

Analyses of radioactivity in the

Site's effluent streambeds demonstrated that there was no measurable buildup of radioactivity in the streambeds during 1993.

Analysis of wild vegetation collected in and along the Site effluent streams on the Site identified very low levels of Strontium-90 radioactivity in some of the samples of Bull Run Stream. Small historical deposits of radioactivity from Site operations which ceased more than 25 years ago could be responsible for the presence of this radioactivity.

Strontium-90 was also detected above minimum detection levels in vegetation samples from the Northeast Area stream and Buono Spring. Since these areas would not have come in contact with historical deposits of radioactivity from Site operations, it is more likely due to atmospheric fallout.

The levels of radioactivity are so low that a person could consume several hundred pounds of this vegetation each year with the highest concentration observed and never exceed the U.S. Nuclear Regulatory Commission (NRC) limits for individuals in unrestricted areas. Actual consumption is not considered a possibility since this vegetation is not used as a human food source. The presence of this radioactivity does not present a risk to the environment or the public health.

\section{RADIATION}

Radiation surveys of the Site indicated that radiation levels were typical of background radiation levels for Western Pennsylvania. Perimeter thermoluminescent dosimetry data show that Site operations did not cause any measurable change in the natural radiation environment surrounding the Site.

Bettis personnel and a representative of the Commonwealth of Pennsylvania, Department of Environmental Resources (PA-DER) performed an environmental radiation survey of a portion of the Bull Run Stream basin in the West Mifflin Community Park. Soil samples were also collected from the surface down to rock at several locations to determine the radioactivity profile in the soil. The survey results confirm that, in addition to the naturally-occurring radioactivity in the area, similar levels of radioactivity from past Bettis operations are present. The survey results also confirm that the low levels of Bettis radioactivity are not migrating or building up in the area. The areas where the residual radioactivity is located are undeveloped and unoccupied. However, even in the unlikely event that a person would spend one hour each day in the area where the radiation level is the highest, the yearly dose received would be well below that allowed for members of the general public by the U.S. Nuclear Regulatory Commission.

\section{AIRBORNE EFFLUENTS}

Airborne radioactivity in Site effluents was controlled using high efficiency particulate filters, wet scrubbing systems and, in some cases, charcoal filters to maintain particulate and gaseous radioactivity releases to as low as reasonably achievable. The amount of long-lived ( $>1$ day half-life) alpha and beta particulate radioactivity released in airborne effluents from the Site was less than 0.000005 Curie.

Comparison of Site airborne effluents with ambient air samples, collected at locations 1.5 to 5 miles from the Site, shows that the Site's airborne particulate effluent was up to 6 times lower than natural background airborne particulate radioactivity. The quantity of long-lived gaseous radioactivity released was less than 0.00001 Curie.

Emissions of non-radiological air effluents were estimated utilizing U.S. Environmental Protection Agency (EPA) emission factors and were well below applicable EPA and Allegheny County standards. Operation of the Site's fuel combustion and heating equipment was conducted in accordance with appropriate Allegheny County Air Pollution Source Operating Permits. 
A risk assessment (RA) was prepared as part of the Site's Resource Conservation and Recovery Act (RCRA) Facility Investigation (RFI). The objective of the assessment was to determine the "reasonable maximum exposure" (RME) of on-site and off-site populations to environmental contamination at the site.

Chemical residues in the environment at Bettis do not pose significant health risks to potentially exposed populations using reasonable maximum exposure assumptions. The only study area with a carcinogenic risk estimate exceeding the comparison criterion of $1.0 \mathrm{E}-06$ is Valley Welding Supply Company (MWSC) soil, with a maximum carcinogenic risk of 1.7E-05. However, exposure (dermal contact, ingestion, and inhalation) for 250 days/year for 25 years is required to achieve this risk. This risk is believed to be highly conservative given that the contaminated portions of the WWSC property are in infrequently accessed or undeveloped locations. In reality, the risk at WWSC is likely to be much less than 1.0E-06.

\section{DOSE-TO-MAN}

Radiation exposure to the general public from Site airborne releases was too low to measure and could only be estimated using conservative, EPA authorized calculational models. The resultant evaluation of all exposure pathways conservatively estimated a maximum annual hypothetical dose range of 0.3 to 2.6 millirem to an individual off-site. Realistically, the actual maximum annual dose would approach 0.3 millirem. However, using the larger value of 2.6 millirem, the dose is only $2.6 \%$ of the conservative numerical guide established for members of the general public by the NRC and DOE. The annual dose to the population from Site operations within a 50-mile radius of the Site was conservatively estimated to be about 3.0 man-rem. This dose is negligible when compared to the approximately 960,000 man-rem received by this population from natural background radiation.
Chemically hazardous materials are not manufactured or disposed of at the Site. Small quantities of chemically hazardous wastes were generated during site operations. These materials were handled, controlled and stored by trained personnel in accordance with applicable federal and state permits. Disposal was arranged with waste vendors operating under State and Federal permits.

\section{SOLID RADIOACTIVE WASTE}

The volume of solid, low-level radioactive waste was minimized by a program to limit the materials that could become contaminated and by waste compaction. Solid, low-level radioactive wastes that were generated at the Site were packaged in strong, tight containers approved by the U.S. Department of Transportation. Shipment of this waste to DOE-owned disposal facilities was controlled by written procedures to ensure compliance with state and federal regulations. The Site has always shipped its radioactive waste out-of-state for disposal.

During 1993, 575 cubic meters of low-level radioactive waste were shipped from the Site. This is less than 1 percent of the total low-level radioactive waste typically dispositioned annually by DOE-owned facilities.

\section{ENVIRONMENTAL ASSESSMENTS}

In 1988, a Preliminary Assessment and Site Inspection (PA/SI) Report was completed for Bettis to meet the requirements of Section 120 of the Comprehensive Environmental Response, Compensation, and Liability Act (CERCLA) as amended by the Superfund Amendments and Reauthorization Act of 1986 (SARA). During 1989, EPA completed their review of the Bettis PA/SI and concluded that no further action under CERCLA was required for the site.

During 1990 an Administrative Order on Consent (Consent Order) issued under Section 3008(h) of RCRA was signed by 
the Pittsburgh Naval Reactors Office (PNR) and EPA, Region III.

The Consent Order requires that a RFI and Corrective Measures Study (CMS) be conducted. The RFI was conducted to characterize the site and the CMS is to determine site-specific remediation alternatives. The RFI workplans were approved by the EPA in 1991. Ground water well installation and the ground water, surface water, soil, sediment and air sampling specified in RFI workplans were completed in 1993. The draft RFI report was submitted to the EPA in December of 1993.

\section{COMPLIANCE SUMMARY}

During 1993 Bettis operations remained in compliance with existing permits and applicable regulations governing use, emission, transportation and disposal of solid, liquid, and gaseous materials and wastes. Operations during 1993 at the Site did not result in any significant release of radioactivity or hazardous materials to the environment.

Also during 1993, the Commonwealth of Pennsylvania, Department of Environmental Resources (PA-DER) conducted an on-site inspection of the hazardous waste program at Bettis. The Site was found to be in compliance with all applicable regulations. No deficiencies were identified during these inspections.

\section{CONCLUSION}

Operations at the Bettis Atomic Power Laboratory-Pittsburgh Site during 1993 did not have any adverse effect on the quality of the environment at the Site or in the surrounding communities. 


\section{TABLE 1}

\section{RADIOLOGICAL ENVIRONMENTAL MONITORING PROGRAM ${ }^{(1)}$}

\section{Sample}

1. Liquid Effluents
a. Bull Run

b. NE Area

2. Influent Drinking Weekly Grab Water

3. Precipitation

4. Ground water
a. Springs On-site
b. Springs Off-site
c. On-site Wells
d. Off-site Wells
e. Runoff

5. Sanitary Effluent Weekly Grab

6. Stream Sediments and Vegetation
a. Bull Run
b. NE Area
c. Thompson Run
d. Streets Run

7. Soil
a. IWS Runoff Area
Biennial Grab

\section{Analysis \\ Frequency $^{(2)}$}

Weekly

Quarterly Composite of Weekly Samples

Annual Composite of Weekly Samples

Weekly

Quarterly Composite of Weekly Samples

Annual Composite of Weekly Samples

Continuous

Annual Grab

Weekly Grab

Semiannual Grab (Sediment)

Annual Grab (Vegetation)
Weekly

Quarterly Composite of Weekly Samples

Annual Composite of Weekly Samples

Annually

Weekly

Quarterly Composite of Weekly Samples

Annual Composite of Weekly Samples

Semiannually (Sediment)

Annually (Vegetation)
Biennially
Routine

Analyses

Gross alpha, beta Gross alpha, beta Sr-89, 90

Gamma Emitters

Gross alpha, beta

Gross alpha, beta Sr-89, 90

Gamma Emitters Gross alpha, beta Gross alpha, beta Sr-89, 90

Gamma Emitters

Gross alpha, beta Gamma Emitters Sr-89, 90

Gross alpha, beta

Sr-89, 90

Gamma Emitters

Gross alpha, beta Sr-89, 90

Gamma Emitters

(Sediment)

Sr-89, 90

Gamma Emitters

(Negetation)

Gross alpha, beta Sr-90, Gamma Emitters

8. Radiation
a. Site Perimeter
Survey
(PRM-7)
Annually
Gamma Exposure 
TABLE 1

RADIOLOGICAL ENVIRONMENTAL MONITORING PROGRAM ${ }^{(1)}$

Sample
b. Bull Run/ Thompson Run
c. IWS Run-On/ Runoff
d. On-site TLDs
e. Off-site TLDs

9. Environmental Air
a. Large, PA
b. Duquesne
Substation located in West Mifflin

\section{Analysis \\ Frequency $^{(2)}$}

Survey (PRM-7)

Survey (PRM-7)

Continuous

Continuous

Continuous

Every Fifth Year

Bi-annually

Quarterly

Quarterly

Weekly

Routine

Analyses

Gamma Exposure

Gamma Exposure

Gamma Exposure

Gamma Exposure

Gross alpha, beta

10. Airborne Effluent
a. Particulate
Continuous
Semi-weekly, Weekly Gross alpha, beta Quarterly
Quarterly Composite Gross alpha, beta of Semi-weekly and Weekly Samples
Sr-89, 90*
Gamma Emitters
b. Gaseous
Continuous
Weekly
Gross beta*
Gamma Emitters*
1) Radon
Annual Grab
Annually
Radon 220, 222*

(1)These monitoring programs comply with DOE Order 5400.1.

${ }^{\text {(2) Minimum analysis frequencies }}$

${ }^{*}$ On selected exhausts 
TABLE 2

NON-RADIOLOGICAL ENVIRONMENTAL MONITORING PROGRAM ${ }^{(1)}$

Sample

1. Liquid Effluents

a. Bull Run

b. NE Area
Sampling

Method

Grab

Grab

Grab

c. Sanitary

Sewer at

Location

SAN-10

Grab

2. Influent

Municipal Water

Supply

Analysis

Frequency $^{(2)}$ Routine Analysis Performed

Semimonthly dissolved oxygen, fecal coliforms, oil and grease, $\mathrm{pH}$, suspended solids, temperature

Semiannually alkalinity, aluminum, ammonia, chloride, color, fluoride, hardness, iron (dissolved), iron (total), manganese, nitrate, nitrite, osmotic pressure, phenols, sulfate, surfactants, total dissolved solids, threshold odor, turbidity

Annually

antimony, arsenic, base/neutrals and acids, beryllium, cadmium, chromium (hexavalent), chromium (total), copper, cyanide (free), lead, mercury, nickel, pesticides, polychlorinated biphenyls, selenium, silver, thallium, volatile organic compounds, zinc.

Semiannually

biochemical oxygen demand, dissolved oxygen, oil and grease, $\mathrm{pH}$, temperature.

Annually

chromium (hexavalent), chromium (total), cyanide (free), lead, mercury, silver.

Grab

Semimonthly

dissolved oxygen, fecal coliforms, oil and grease, $\mathrm{pH}$, suspended solids, temperature.

Grab
Semiannually alkalinity, aluminum, ammonia, chloride, color, fluoride, hardness, iron (dissolved), iron (total), manganese, nitrate, nitrite, osmotic pressure, phenols, sulfate, surfactants, total dissolved solids, threshold odor, turbidity 
TABLE 2

NON-RADIOLOGICAL ENVIRONMENTAL MONITORING PROGRAM ${ }^{(1)}$

Sample

Sampling Analysis

Method Frequency ${ }^{(2)}$

Routine Analysis Performed

Grab Annually

antimony, arsenic, base/neutrals and

acids, beryllium, cadmium, chromium

(hexavalent), chromium (total), copper, cyanide (free), lead, mercury, nickel, pesticides, polychlorinated biphenyls, selenium, silver, thallium, volatile organic compounds, zinc

(1) Of the various programs specified herein, only the monitoring programs for $\mathrm{pH}$, oil and grease, and suspended solids are required by the Site's NPDES permit. Other programs are conducted as a matter of local policy.

(2) Minimum analysis frequencies. 


\section{INTRODUCTION}

\section{PURPOSE}

This document summarizes for calendar year 1993 the results of the radiological and non-radiological environmental monitoring programs at the Bettis Laboratory-Pittsburgh Site. This report also discusses the Site programs for handling and off-site disposal of radioactive waste and chemically hazardous waste. The report is prepared in conformance with the DOE requirements.

\section{SITE BACKGROUND AND ENVIRONMENTAL SETTING}

The Bettis Site is operated by the Westinghouse Electric Corporation for the DOE and is engaged in the design and development of naval nuclear propulsion plants. Operations conducted at the Site include development and examination of nuclear fuel materials and reactor materials.

The Site is situated on a 202 acre tract of land in the Borough of West Mifflin, and is located approximately 8 miles southeast of the downtown section of Pittsburgh, Pennsylvania. A heavily wooded area borders the site on the east. This property is owned by the Borough of West Mifflin. A portion of this property has been developed into the West Mifflin Community Park. A fence has been erected to prevent free access to the Bettis-Pittsburgh site property from the park area. An industrial district is located along the northern boundary of the Bettis-Pittsburgh site. Commercial and residential developments border the site on the south and west. Two public roadways run along the length of the southern perimeter of the property and a public railroad runs along the northern end. The land use of the region surrounding the Site is largely industrial and residential. The total population within a 50 mile radius of the site is approximately $3,200,000$. The location of the Site with respect to the surrounding communities is shown in Figure 1.

\section{PHYSIOGRAPHY}

Physiography is a term used to denote the description of the natural physical landforms of an area. The Site is located within Allegheny County, Pennsylvania, which is situated within the Allegheny Plateau physiographic province of North America. Stream erosion of a formerly raised plateau produced the present rugged land surface. The geologic formations are generally flat-lying or gently folded and inclined. Stream frequency and the percentage of the land found in slopes decrease with distance from the major drainageways, such as the Monongahela River.

\section{TOPOGRAPHY}

The Bettis Laboratory-Pittsburgh Site is located approximately 6000 feet west of the Monongahela River. The maximum elevation at the Bettis Site is approximately 1200 feet. The minimum elevation, found at the point where Bull Run Stream leaves the southeastern portion of the site, is approximately 1020 feet. The normal pool elevation of the Monongahela River near Bettis-Pittsburgh is approximately 720 feet. Thus the developed portions of the BettisPittsburgh Site are approximately 480 feet above the surface of the Monongahela River.

Surface drainage at the Site is primarily toward the east, discharging into Bull Run Stream and its tributaries. The waters in the Bull Run Stream originating from the site include once-through non-contact cooling water, storm water runoff and process waters. The Bull Run 


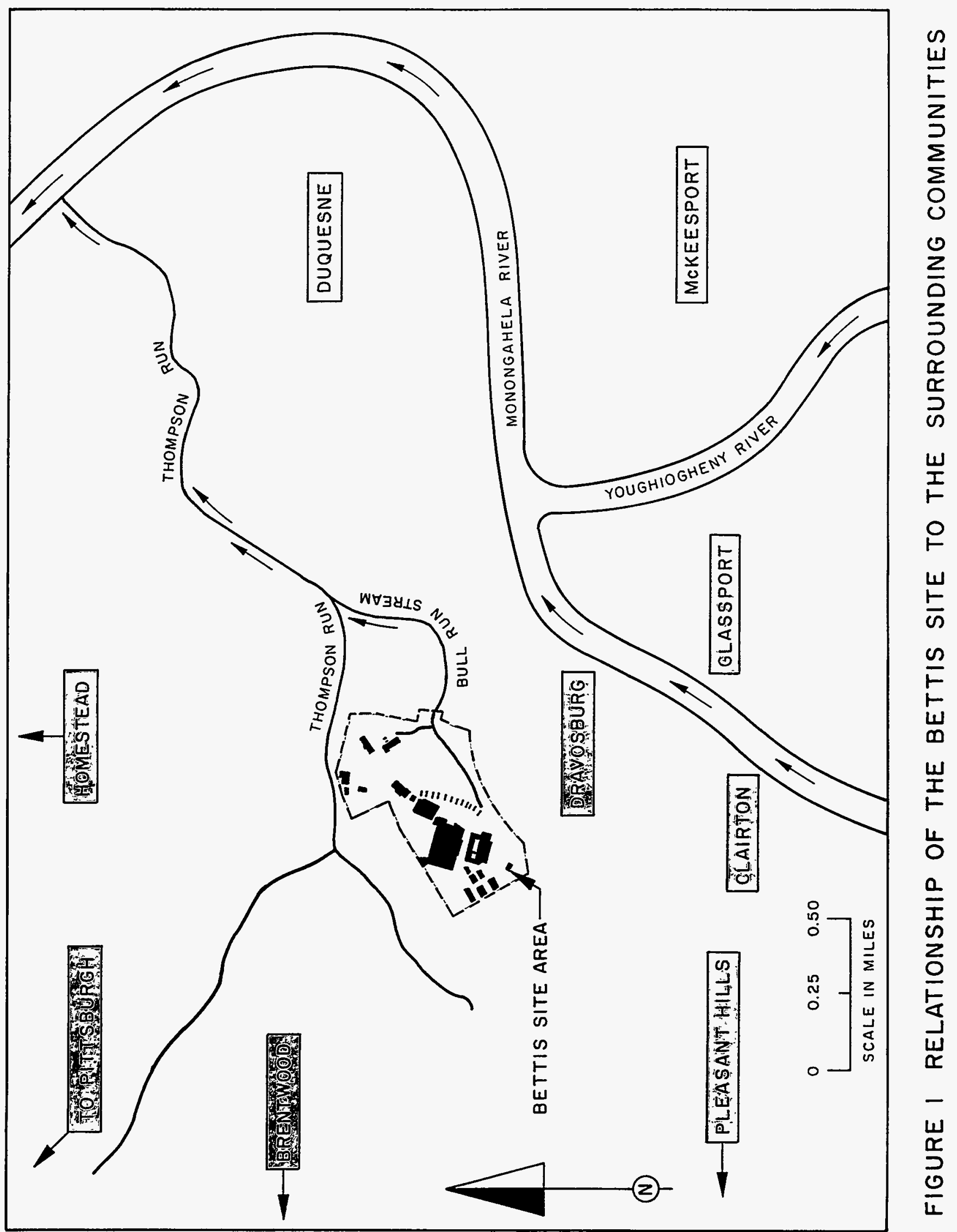


Stream flows approximately 1.4 miles before joining Thompson Run Stream which empties, approximately 2.6 miles downstream, into the Monongahela River in the City of Duquesne. A narrow, mostly sloped area that includes a small developed portion of the Site drains northwest directly into Thompson Run Stream.

Because of the location and elevation of the Site, flooding from local streams or rivers is not possible. Some minor bank overflowing from Bull Run Stream may occur downstream from the Site during heavy rainfall.

Several springs discharge on the Site property. The largest of these, Buono Spring, RQ-20 Spring, and Northeast Spring, are on the eastern, non-developed portion of the site. These are permanent springs with varying flows that are reflective of the seasons. They drain into the Bull Run Stream drainage basin. A few smaller, intermittent springs also discharge into the Bull Run Stream drainage basin.

\section{SOILS}

The soils at the Site are residual in origin, having been formed by weathering of the underlying Monongahela Group bedrock or are the result of filling operations. The soils on-site are classified as the Culleoka and Urban Land-Guernsey soils. The Culleoka soils are characterized as moderately deep, well drained soils formed from shale and fine grained sandstone bedrock. They generally occur on upland slopes, have moderate permeability and normally a water table below four feet throughout the year. The surface soil can be described as dark brown, granular silt loam, while the subsoil is yellowish-brown, blocky silt loam to channery clay loam. The substrata consists of yellowish-brown, massive, very channery clay loam.

The Urban Land-Guernsey soils are described as variable consisting of disturbed land resulting from cut and fill operations and subsequent coverage with urban works. These soils occur in a complex pattern with Culleoka soils which are described above. The Guernsey soils are characterized as deep, well drained soils with a slow permeability and a winter water table within 1 or 2 feet of the surface. This soil type is formed from interbedded clay shale, shale and limestone bedrock.

None of the Site land is utilized for agrarian purposes.

\section{GEOLOGY}

\section{REGIONAL STRATIGRAPHY}

The geologic formations that underlie the portion of Allegheny County in which the Site is located are part of the Pennsylvanian System. The Monongahela, Conemaugh and Allegheny Groups, all part of the Pennsylvanian System, underly the site. The Monongahela Group, the uppermost group, includes beds of limestone, variable shales, discontinuous layers of sandstone and coal beds. Several of these coal beds had significant economic importance. The base of the Pittsburgh coal marks the base of the Monongahela Group. Table 3 presents a generalized description of the rock strata beneath the Site.

Some of the important beds in the Monongahela Group are the Uniontown Limestone, Benwood Limestone, Sewickley Sandstone, Fishpot Limestone, Pittsburgh Sandstone, and the Redstone and Pittsburgh Coal. Core borings taken on-site confirm that the bedrock consists of layers of limestone, shale, and sandstone.

Extensive mining of the Pittsburgh Coal seam has occurred to the west and south of the site as well as under the BettisPittsburgh Site. The Pittsburgh Coal seam lies about 200-250 feet below the active portion of the site. Most of the Pittsburgh Coal that can be mined has been removed. There are no current coal mining activities in this area. 
TABLE 3

GENERALIZED SECTION OF ROCK STRATA BENEATH THE BETTIS LABORATORY

\begin{tabular}{|c|c|c|c|c|}
\hline \multicolumn{3}{|c|}{ CLASSIFICATION } & \multirow[b]{2}{*}{ Strata } & \multirow[b]{2}{*}{ Remarks } \\
\hline System & Group & Formation & & \\
\hline \multirow{4}{*}{$\begin{array}{l}P \\
\mathbf{E} \\
\mathbf{N} \\
\mathbf{N} \\
\mathbf{S} \\
\mathbf{Y} \\
\mathbf{L} \\
\mathbf{V} \\
\mathbf{A} \\
\mathbf{N} \\
\mathbf{I} \\
\mathbf{A} \\
\mathbf{N}\end{array}$} & Monongahela & Pittsburgh & $\begin{array}{l}\text { Cyclic sequences of } \\
\text { shale, limestone, } \\
\text { claystone, and coal. } \\
\text { Pittsburgh coal seam } \\
\text { is bottom stratum. }\end{array}$ & $\begin{array}{l}\text { Extends from at or near } \\
\text { surface down to } \\
\text { Pittsburgh coal. } \\
\text { Mined out about } 200-250 \\
\text { feet below Bettis. }\end{array}$ \\
\hline & \multirow[t]{2}{*}{ Conemaugh } & Casselman & $\begin{array}{l}\text { Cyclic sequences of } \\
\text { sandstone, shale, silty } \\
\text { claystone ("red beds"), } \\
\text { and thin limestone and } \\
\text { coal. }\end{array}$ & $\begin{array}{l}\text { Coal deposits of this } \\
\text { group not normally } \\
\text { mined. formation is } \\
\text { about } 250-300 \text { feet thick; } \\
\text { base is near normal level } \\
\text { of Monongahela River. }\end{array}$ \\
\hline & & Glenshaw & $\begin{array}{l}\text { Cyclic sequences of } \\
\text { sandstone, shale, red } \\
\text { beds, and thin } \\
\text { limestone and coal; } \\
\text { fossiliferous limestone. }\end{array}$ & $\begin{array}{l}\text { Formation is } 300 \text { to } 380 \\
\text { feet thick. }\end{array}$ \\
\hline & Allegheny & Freeport & $\begin{array}{l}\text { Upper Freeport coal } \\
\text { seam is top stratum. }\end{array}$ & $\begin{array}{l}\text { Major coal bed, } 600 \text { to } \\
630 \text { feet below level of } \\
\text { Pittsburgh coal. }\end{array}$ \\
\hline \multicolumn{5}{|c|}{$\begin{array}{l}\text { Pennsylvanian system rocks extend down } \\
\text { to about sea level. }\end{array}$} \\
\hline
\end{tabular}




\section{STRUCTURAL GEOLOGY}

The geologic formations under the BettisPittsburgh site are part of a regional trough that plunges (becomes progressively lower) $530^{\circ} \mathrm{W}$ at a rate of 20 to 30 feet per mile. At the Site, the Pittsburgh Coal has a dip of $1 \%$ to the southeast. Secondary folding subparallel to the major plunge has created anticlinal and synclinal structures whose limbs rise or dip at varied rates. The axes of these folds trend about $\mathrm{N} 30^{\circ} \mathrm{E}$.

\section{HYDROGEOLOGY}

The Site is underlain by the geologic units of the Pennsylvanian Monongahela Group. The Monongahela Group is not an important local aquifer. Well yields from the Monongahela Group range from less than 1 to 30 gallons per minute (gpm). Pump tests at Bettis-Pittsburgh in the Sewickley Sandstone water-bearing zone could not sustain flow rates of $1-3 \mathrm{gpm}$.

The topographic features of the area such as high hills cut by major stream valleys greatly effect the direction and depth of water tables. There may be subregional ground water regimes where the discharge of the ground water is to local streams. In cases where the stream channels lie below the water table, some aquifers may discharge on valley slopes.

Based on data obtained through rock coring, monitoring well drilling, geophysical logging, and ground water elevation monitoring, the ground water under the site is present in five different water-bearing zones. The water-bearing zones in descending order are: the Perched zone, the Benwood Limestone zone, the Sewickley Sandstone zone, the Pittsburgh Sandstone zone, and the Pittsburgh Coal zone. The Pittsburgh Coal water-bearing zone represents the basal ground water flow at Bettis. These water-bearing zones are described in detail in Reference (1).

There are no springs or wells on-site or in the local, hydraulically downgradient area which are known to be used for drinking water, industrial or irrigation purposes.

\section{METEOROLOGY}

The Bettis-Pittsburgh Site has a humid, continental type of climate modified only slightly by its nearness to the Atlantic Seaboard and the Great Lakes. The Bettis-Pittsburgh Site is a little over 100 miles southeast of Lake Erie.

Data accumulated by the Site meteorological monitoring system during 1993 indicated that prevailing winds for the Site occurred about $30 \%$ of the time from the southwest quadrant and about $33 \%$ of the time from the northwest quadrant. Wind speeds of 5-12 mph occurred about $65 \%$ of the time and less than $5 \mathrm{mph}$ about $25 \%$ of the time. Average daily temperatures during the year ranged from 27 to $74^{\circ} \mathrm{F}$. The annual rain and snowfall amounted to 32 inches of water. 


\section{ENVIRONMENTAL MONITORING}

Descriptions of the Site's radiological and non-radiological environmental programs are provided in References (2) and (3), respectively. These monitoring programs are outlined in the following sections and summarized in Tables 1 and 2.

\section{A. LIQUID EFFLUENTS}

The purpose of the liquid effluent monitoring programs is to determine the effectiveness of control methods and to measure concentrations in effluents for comparison with applicable standards and natural background levels. In addition to monitoring liquid effluents from the Site, samples of precipitation and influent city water are monitored and used for background comparisons. During the RFI, samples of the surface water in Bull Run, Northeast and Thompson Run Streams were collected and analyzed.

\section{Sources and Treatment}

The principal sources of non-sanitary, liquid effluents are once-through city water used for cooling purposes, surface runoff of precipitation, and process water.

The total liquid effluent released from the Site through the storm sewer monitoring stations in 1993 was $8.6 \times 10^{7}$ gallons. Approximately $89 \%$ of this volume was released at the Bull Run monitoring station and the remaining $11 \%$ of the liquid was released at the Northeast Area monitoring station. Figure 2 shows the locations of these two monitoring stations. The discharged effluents comprise most of the flow of Bull Run, which empties into Thompson Run about one mile below the site. Thompson Run flows about 2.6 miles before emptying into the Monongahela River. There are no wells or springs on-site which are used for drinking or irrigation purposes. The Monongahela River is used as a raw water source for public water supply serving the Site and some surrounding communities.

During 1993, as in previous years, a water reuse system was used whereby liquids containing radioactivity were collected, processed, and reused in select Site operations.

Water used for sanitary purposes was discharged to the West Mifflin Borough, Thompson Run Sewage Treatment Plant which discharged treated effluent to Thompson Run.

During 1993 approximately 1,392 gallons of ground water generated from the RFI and other ground water sampling efforts were discharged to the sanitary sewer for treatment at the Thompson Run Sewage Treatment Plant. This water resulted from sampling the site's ground water monitoring wells. The ground water contains traces of VOCs including PCE, trichloroethylene (TCE), and vinyl chloride which were within allowable release limits to the Treatment Plant. PNR notified the Borough of West Mifflin, the EPA and the PA-DER concerning the discharges, as required by applicable regulations.

\section{Effluent Liquid Monitoring}

The samples and analyses specified below constitute the minimum samples and analyses conducted at Bettis-Pittsburgh during 1993. Normally, additional samples and analyses are performed whenever radioactivity or chemical concentrations are detected in excess of normal or expected levels.

Radiological: Water samples of nonsanitary, effluent liquid were collected continuously at the Bull Run and Northeast Area monitoring stations. Weekly, these samples were picked up and analyzed for gross alpha and gross beta radioactivity. Quarterly, composites of the weekly 


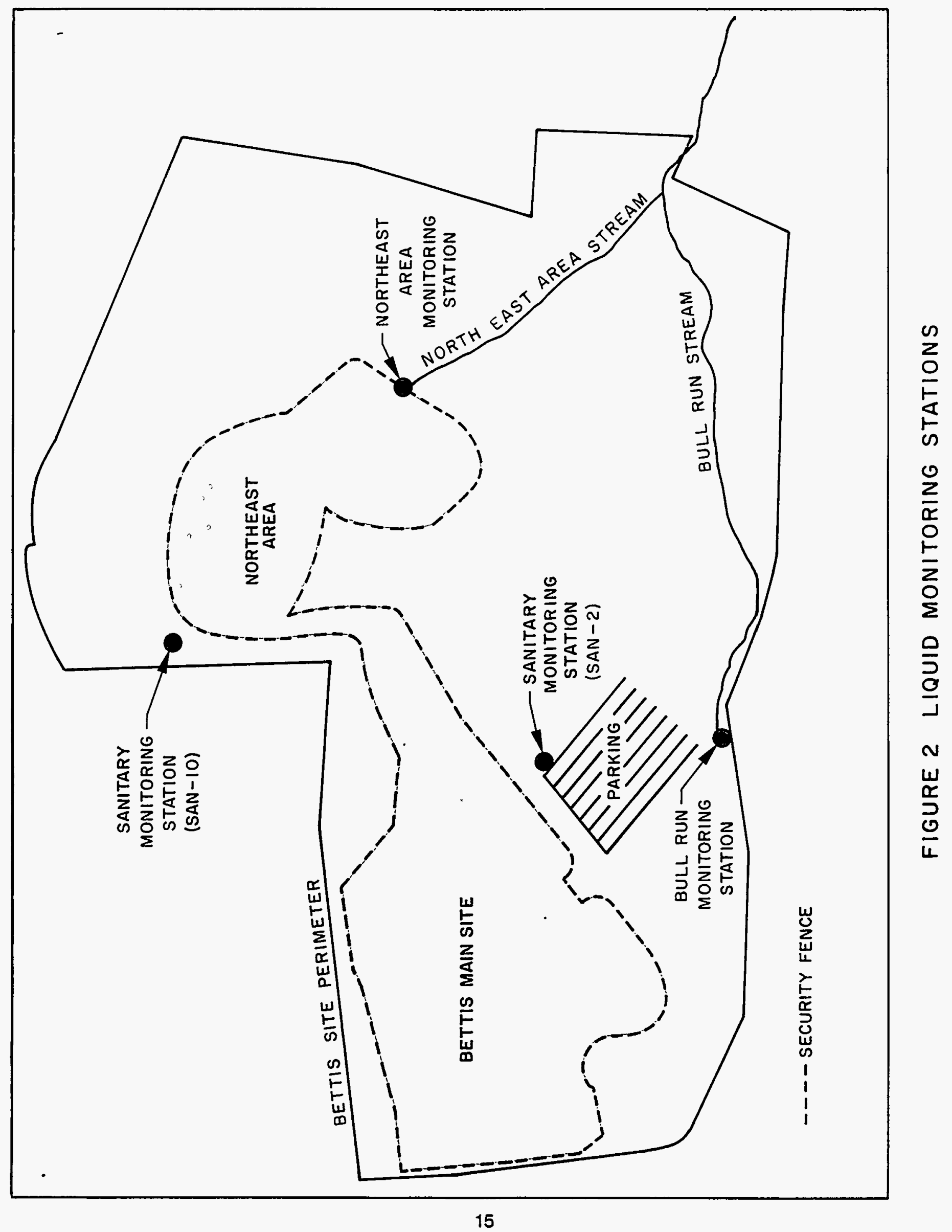


samples were analyzed for gross alpha and gross beta radioactivity and radiostrontium. Gamma spectrometry was performed annually on a composite of the weekly samples. Influent city water and precipitation samples were analyzed similarly to effluent liquid samples.

Grab samples of sanitary effluent were collected at the outfall of the main site area (location SAN-2), shown on Figure 2. These samples were analyzed weekly for gross alpha and gross beta radioactivity. Quarterly, a composite of the weekly samples from SAN-2 was analyzed for radiostrontium. Annually, a composite of the weekly samples from SAN-2 was analyzed for non-naturally occurring gamma emitters. Semiannual grab samples of sanitary effluent were collected at the outfall of the entire Bettis Site (location SAN-10). These samples were analyzed on both occasions for gross alpha and gross beta radioactivity.

Non-Radiological: Samples of effluents discharged through the Bull Run and Northeast Area monitoring stations were collected on at least a monthly basis. Semimonthly, grab samples were collected and analyzed for dissolved oxygen, fecal coliforms, oil and grease, $\mathrm{pH}$, suspended solids, and temperature. Semiannually, grab samples were collected and analyzed for alkalinity, aluminum, ammonia, chloride, color, fluoride, hardness, iron (dissolved), iron (total), manganese, nitrate, nitrite, osmotic pressure, phenols, sulfate, surfactants, total dissolved solids, threshold odor, and turbidity. Annually, grab samples were collected and analyzed for antimony, arsenic, base/neutrals and acids, beryllium, cadmium, chromium (hexavalent), chromium (total), copper, cyanide (free), lead, mercury, nickel, pesticides, polychlorinated biphenyls, selenium, silver, thallium, volatile organic compounds, and zinc.

Grab samples of the influent municipal water supply, which comprises a significant portion of the Site's discharges, were collected at the same frequencies and analyzed for the same parameters described above for the Bull Run and Northeast Area effluents.

Semiannually, grab samples of sanitary effluent were collected at the outfall of the entire Bettis Site (location SAN-10) and analyzed for biochemical oxygen demand, dissolved oxygen, oil and grease, $\mathrm{pH}$, and temperature. Annually, grab samples of sanitary effluent were collected and analyzed for chromium (hexavalent), chromium (total), cyanide (free), lead, mercury, and silver.

\section{Liquid Analyses}

Radiological: Liquid samples (liquid effluent, city water, precipitation, sanitary, groundwater, etc.) were prepared for analysis by evaporation of at least 100 milliliter aliquots of liquid. The alpha and beta radioactivity of the samples were measured using a low background proportional counter. Typical minimum detection levels achieved for alpha and beta radioactivity for $100 \mathrm{ml}$ samples were $2.0 \times 10^{-9} \mu \mathrm{Ci} / \mathrm{ml}$ and $3.0 \times 10^{-9} \mu \mathrm{Ci} / \mathrm{ml}$, respectively.

Gamma spectrometry was also performed to identify gamma-emitting radionuclides using a Germanium-Lithium (GeLi) or a Germanium detector and a multichannel analyzer. For samples collected weekly, a typical minimum detection level for Cesium-137 and Cobalt-60 in a $500 \mathrm{ml}$ sample was $5.0 \times 10^{-9} \mu \mathrm{Ci} / \mathrm{ml}$. A typical minimum detection level for Cesium-137 and Cobalt- 60 in the annual composite was $8.0 \times 10^{-11} \mu \mathrm{Ci} / \mathrm{ml}$.

Radiostrontium analyses were performed on selected samples using a standard strontium radiochemical procedure. A typical minimum detection level achieved for Strontium-90 was $7.0 \times 10^{-10} \mu \mathrm{Ci} / \mathrm{ml}$. 
Non-Radiological: Analyses of effluent and influent samples were performed using test methods described in Reference (4) or other EPA-approved methods. Detection limits and standards are listed in Tables 5 and 6.

\section{Liquid Monitoring Results and Conclusions}

Radiological: Due to utilization of a water reuse system and strict adherence to procedures governing control of radioactive liquids, no radioactive liquids were released to the environment at the Bull Run or Northeast Area discharge stations.

The results of the weekly analyses for alpha radioactivity in the site's effluents showed that the levels were very near or below the minimum detection level and were typical of the background alpha radioactivity levels measured in the city water influent and precipitation. None of 52 alpha radioactivity measurements of the effluents exceeded one-third of the limit of Reference (5) for alpha radioactivity, based on Thorium-232, in water in uncontrolled areas.

The results of the weekly analyses for beta radioactivity in the site's effluents showed that the beta radioactivity levels, although slightly higher because of the presence of natural radioactivity associated with dissolved solids contained in the effluent, were typical of the levels measured in the city water influent and precipitation. None of the 52 beta radioactivity measurements of the effluents exceeded 1/50th of the limit of Reference (5) for beta radioactivity, based on Strontium-90, in water in uncontrolled areas.

Table 4 presents the quarterly composite sample results of the alpha, beta, and Strontium -89 and -90 radioactivity analyses for the effluents from the Bull Run and Northeast Area discharge stations, as well as for precipitation and city water samples. The quarterly composite results show that the radioactivity in the site's effluents was similar, within measurement uncertainties, to radioactivity in city water and precipitation.

The results of the gamma analyses for the annual composited water samples are also shown in Table 4. The results indicate that the levels of non-naturally occurring, gamma-emitting radionuclides in the effluents from the Bull Run and Northeast Area discharge stations were below the minimum detection levels and indistinguishable from precipitation and influent city water.

The alpha and beta radioactivity levels in sanitary sewer samples were typical of background levels. The alpha levels in the sanitary effluent were generally near or below the minimum detection level. The beta levels were slightly higher than the alpha levels due primarily to the presence of Potassium-40 which occurs naturally in the body waste excretions.

During 1993 the gross alpha levels in the sanitary effluent never exceeded the local control level of $1.0 \times 10^{-8} \mu \mathrm{Ci} / \mathrm{ml}$. In three samples, the gross beta levels in the sanitary effluent exceeded the local control level of $70 \mathrm{pCi} / \mathrm{l}\left(7.0 \times 10^{-8} \mu \mathrm{Ci} / \mathrm{ml}\right)$. The maximum level was $1100 \mathrm{pCi} /$. Specific analyses of these three samples did not identify the presence of any Bettisgenerated radioactivity but did identify the medical diagnostic radioisotope

Thallium-201. It was concluded that Bettisgenerated radioactivity was not released to the environment.

Non-Radiological: A summary of the results of water quality (chemical constituents) measurements for influent city water and effluent water from the Site are presented in Tables 5 and 6 . Since a significant portion of the effluent is noncontact cooling water, the quality of the effluent is influenced by the influent city water quality. Tables 5 and 6 also list the discharge standards established in the Site's NPDES permit and guidelines derived from the Pennsylvania Code, Title 25, Environmental Resources, Chapter 93, 
TABLE 4

LIQUID EFFLUENT QUARTERLY AND

ANNUAL RADIOACTIVITY ANALYSIS

CY 1993

RADIOACTIVITY ANALYSES OF QUARTERLY COMPOSITED SAMPLES ${ }^{(1,2)}$

Units $10^{-9} \mu \mathrm{Ci} / \mathrm{ml}$

\begin{tabular}{|c|c|c|c|c|c|}
\hline $\begin{array}{l}\text { Sample } \\
\text { Location }\end{array}$ & $\begin{array}{l}\text { Activity } \\
\text { Analysis }\end{array}$ & 1st Quarter & 2nd Quarter & 3rd Quarter & 4th Quarter \\
\hline Bull Run & $\begin{array}{l}\text { Alpha } \\
\text { Beta } \\
\text { Sr-90 } \\
\text { Sr-89 }\end{array}$ & $\begin{array}{l}\leq 3.3 \\
4.1 \pm 2.8 \\
\leq 1.7 \\
\leq 5.7\end{array}$ & $\begin{array}{l}\leq 1.9 \\
2.6 \pm 2.3 \\
\leq 0.82 \\
\leq 3.6\end{array}$ & $\begin{array}{l}\leq 2.1 \\
\leq 1.9 \\
\leq 0.67 \\
\leq 1.1\end{array}$ & $\begin{array}{l}\leq 1.8 \\
\leq 1.8 \\
\leq 0.45 \\
\leq 1.3\end{array}$ \\
\hline $\begin{array}{l}\text { Northeast } \\
\text { Area }\end{array}$ & $\begin{array}{l}\text { Alpha } \\
\text { Beta } \\
\text { Sr-90 } \\
\text { Sr-89 }\end{array}$ & $\begin{array}{l}\leq 4.6 \\
\leq 2.3 \\
\leq 1.9 \\
\leq 6.3\end{array}$ & $\begin{array}{l}\leq 2.6 \\
\leq 2.0 \\
\leq 0.47 \\
\leq 2.0\end{array}$ & $\begin{array}{l}\leq 2.4 \\
\leq 2.0 \\
\leq 0.75 \\
\leq 1.3\end{array}$ & $\begin{array}{l}\leq 2.2 \\
\leq 1.9 \\
\leq 0.41 \\
\leq 1.2\end{array}$ \\
\hline Precipitation & $\begin{array}{l}\text { Alpha } \\
\text { Beta } \\
\text { Sr-90 } \\
\text { Sr-89 }\end{array}$ & $\begin{array}{l}\leq 0.85 \\
4.7 \pm 1.9 \\
\leq 1.7 \\
\leq 3.6\end{array}$ & $\begin{array}{l}\leq 0.85 \\
\leq 1.4 \\
\leq .47 \\
\leq 1.9\end{array}$ & $\begin{array}{l}\leq 0.85 \\
\leq 1.6 \\
\leq 1.0 \\
\leq 1.9\end{array}$ & $\begin{array}{l}\leq 0.85 \\
\leq 1.5 \\
\leq 0.45 \\
\leq 1.3\end{array}$ \\
\hline City Water & $\begin{array}{l}\text { Alpha } \\
\text { Beta } \\
\text { Sr-90 } \\
\text { Sr-89 }\end{array}$ & $\begin{array}{l}\leq 1.3 \\
\leq 1.7 \\
\leq 1.7 \\
\leq 5.7\end{array}$ & $\begin{array}{l}\leq 1.5 \\
\leq 1.7 \\
\leq 0.44 \\
\leq 1.8\end{array}$ & $\begin{array}{l}\leq 2.0 \\
\leq 1.9 \\
\leq 0.77 \\
\leq 1.3\end{array}$ & $\begin{array}{l}\leq 1.3 \\
\leq 1.7 \\
\leq 0.38 \\
\leq 1.1\end{array}$ \\
\hline
\end{tabular}

GAMMA RADIOACTIVITY ANALYSES OF ANNUAL COMPOSITED SAMPLES ${ }^{(1,2)}$

Units: $10^{-9} \mu \mathrm{Ci} / \mathrm{ml}$

$\begin{array}{llll}\text { Composite Sample } & \underline{\text { Co-60 }} & \text { Cs-137 } & \text { Cs-134 } \\ \text { Bull Run } & \leq 0.13 & \leq 0.11 & \leq 0.13 \\ \text { Northeast Area } & \leq 0.13 & \leq 0.15 & \leq 0.17 \\ \text { Precipitation } & \leq 0.19 & \leq 0.18 & \leq 0.25 \\ \text { City Water } & \leq 0.12 & \leq 0.12 . & \leq 0.15\end{array}$

(1) Uncertainties are based on counting statistics and are expressed at the $95 \%$ confidence level.

(2) $\leq$ signifies the data are at or below the minimum detection level (MDL). The MDL is a function of the sample size, the chemical recovery yield, count time, and the presence of other dissolved materials. While the MDLs vary slightly, the values are all well below the Reference (5) limits for water in uncontrolled areas. Likewise, all of the data which are above MDLs are also well below the Reference (5) limits. 


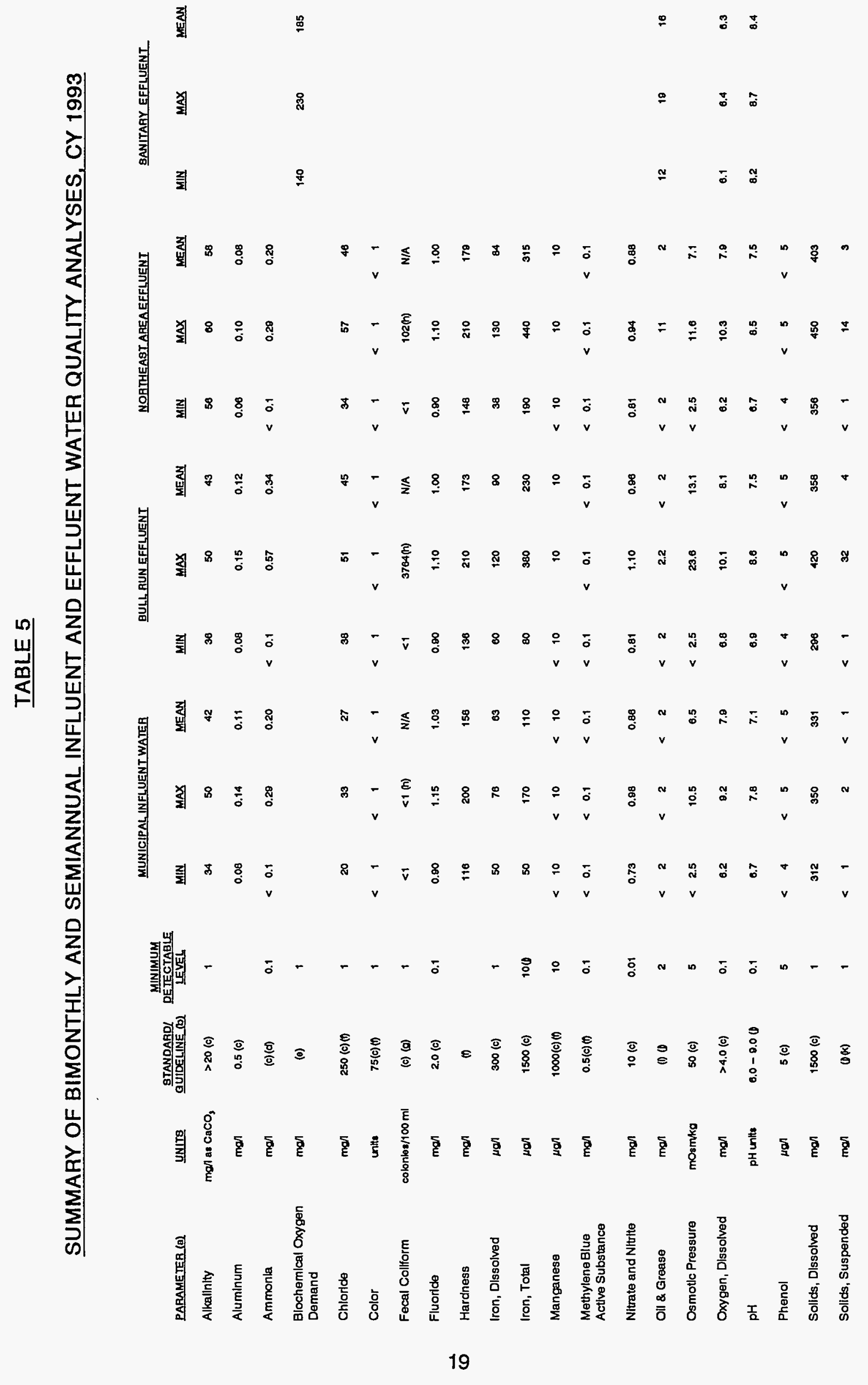




\section{TABLE 5}

\section{SUMMARY OF BIMONTHLY AND SEMIANNUAL INFLUENT AND EFFLUENT WATER QUALITY ANALYSES, CY 1993}

\begin{tabular}{|c|c|c|c|c|c|c|c|c|c|c|c|c|c|c|c|}
\hline \multirow[b]{2}{*}{ PARAMEIER(a) } & \multirow[b]{2}{*}{ UNITS } & \multirow[b]{2}{*}{$\begin{array}{l}\text { BTANDARD/ } \\
\text { GUIDELINE (b) }\end{array}$} & \multirow{2}{*}{$\frac{\text { MINIMUM }}{\text { DETECTABLE }}$} & \multicolumn{3}{|c|}{ MUNIGIPAL INFLUENT WATER } & \multicolumn{3}{|c|}{ BULLL RUN EFFLUENT } & \multicolumn{3}{|c|}{ NORTHEAST AREA EFFLUENT } & \multicolumn{3}{|c|}{ SANITAAY EFFLUENT } \\
\hline & & & & MIN & MAX & MEAN & MIN & MAX & MEAN & MIN & MAX & MEAN & MIN & MAX & MEAN \\
\hline Sulfate & $\mathrm{mgl}$ & $250(c)(1)$ & 1 & 92 & 170 & 131 & 77 & 210 & 144 & 89 & 220 & 160 & & & \\
\hline Temperature & ${ }^{\circ} \mathrm{F}$ & $(\theta)(1)$ & 0.1 & 47 & 82 & $\infty$ & 48 & 81 & e3 & 47 & 82 & 61 & 67 & 71 & 69 \\
\hline Threshald Odor \# & \# & 24 (c) (1) & 1 & $<1$ & $<1$ & $<1$ & $<1$ & $<$ & $<1$ & $<1$ & $<1$ & $<1$ & & & \\
\hline Turbidity & units & $100(0)(0)$ & $5(m)$ & $<0.5$ & $<5$ & $<3$ & 1.0 & $<$ & $<3$ & 0.00 & $<5$ & $<3$ & & & \\
\hline
\end{tabular}

(a) Additional samples of municipal influent water and Bull Run and Northeast Area effluents were collected as part of the RFI.

(b) The standards or guidelines noted are for the Bull Run and Northeast Area effluent and do not apply to sanltary effluent. Applicable sanitary effluent standards or guidellnes are $\mathrm{pH}: 5.5$ to 8.0 and oll and grease: $100 \mathrm{mg} /$ per West Miffilin Ordinance 717.

(c) Guldellne is based on Pennsylvanla Code, Title 25, Department of Environmental Resources, Chapter 83, Water Quality Standards for streams designated for warm water fishes.

(d) Guideline calculated using median pH and temperature measurements for July through September and equals $1.3 \mathrm{mgl}$ for Bull Run effluent and $0.7 \mathrm{mg} /$ for Northeast Area effluent. Guldeline represents the maximum total ammonla concentratlon not to be exceeded at any time.

(e) No speclfic guldeline avallable; however, this parameter provides an Indication of oxygen demanding substances present in the santtary effluent.

(i) No spectile guldeline avallable; however, if a value is noted, it is for comparison purposes only.

(g) Guldeline is 200 colonles/100 $\mathrm{ml}$ for May 1 to September 30 or 2000 colonles/100 $\mathrm{ml}$ for October 2 to April 30 for the geometric mean of five consecutive samples collected on different days.

(h) Value noted is the maximum geometric mean of five consecutive samples.

(i) Standard is $15 \mathrm{mg} / \mathrm{las}$ a monthly average and $30 \mathrm{mg} / \mathrm{ls}$ an Instantaneous maximum.

0) Based on the Nattonal Pollutant Discharge Ellminatlon System Permit for the Bettls Atomic Power Laboratory lssued July 24, 1987 and revised December $15,1987$.

(k) Standard is $25 \mathrm{mg} / \mathrm{l}$ as a monthly average and $50 \mathrm{mg} / \mathrm{las}$ a dally maximum.

(1) Temperature guldellne varles with each month or part of month during the year.

(m) Detection limit changed due to change in analytical procedure used to analyze the sample. 


\section{TABLE 6}

ANNUAL INFLUENT AND EFFLUENT WATER QUALITY ANALYSES - CY $1993^{(\mathrm{a})}$

\begin{tabular}{|c|c|c|c|c|c|c|}
\hline PARAMETER & UNTS & $\begin{array}{l}\text { CONTINUOUS } \\
\text { CONCENTRATION } \\
\text { GUIDEUNE }\end{array}$ & $\begin{array}{l}\text { MAXIMUM } \\
\text { CONCENTRATION } \\
\text { GUIDEUNE }\end{array}$ & $\begin{array}{l}\text { MUNICIPAL } \\
\text { INFLUENT } \\
\text { WATER }\end{array}$ & $\begin{array}{l}\text { BUU RUN } \\
\text { EFFLUENT }\end{array}$ & $\begin{array}{l}\text { NORTHEAST } \\
\text { AREA } \\
\text { EFFLUENT }\end{array}$ \\
\hline Antimony & $\mu \mathrm{g} / \mathrm{l}$ & 219 & 1095 & $<30$ & $<30$ & $<30$ \\
\hline Arsenic & $\mu \mathrm{g} / \mathrm{l}$ & 190 & 360 & $<5$ & $<5$ & $<5$ \\
\hline Base/Neutrals and Acids & $\mu \mathrm{g} / 1$ & $(c)(d)$ & (c)(d) & $(c)(d)$ & (c)(d) & (c)(d) \\
\hline Beryllium & $\mu \mathrm{g} / \mathrm{l}$ & (e) & (e) & $<0.3$ & $<0.3$ & $<0.3$ \\
\hline Chromium, Hexavalent & $\mu \mathrm{g} / \mathrm{l}$ & 11 & 16 & $<10$ & $<10$ & $<10$ \\
\hline Chromium, Total & $\mu \mathrm{g} / \mathrm{l}$ & $300^{(f)}$ & $2436^{(1)}$ & $<10$ & 45 & $<10$ \\
\hline Copper & $\mu \mathrm{g} / \mathrm{l}$ & $17^{(1)}$ & $26^{(\mathfrak{)})}$ & 34 & 17 & 12 \\
\hline Cyanide, Free & $\mu \mathrm{g} / \mathrm{l}$ & 5 & 22 & $<2$ & $<2$ & $<2$ \\
\hline Lead(9) & $\mu \mathrm{g} / \mathrm{l}$ & 5.4 & $138^{(f)}$ & $<3$ & $<3$ & $<3$ \\
\hline Pesticides & $\mu \mathrm{g} / \mathrm{l}$ & (c) (d) & (c)(d) & (c)(d) & (c)(d) & $(c)(d)$ \\
\hline Selenium & $\mu \mathrm{g} / \mathrm{I}$ & 5 & 20 & $<5$ & $<5$ & $<5$ \\
\hline Silver $r^{(1)}$ & $\mu \mathrm{g} / \mathrm{l}$ & 0.2 & $8.2^{(f)}$ & $<0.2$ & $<0.2$ & $<0.2$ \\
\hline Thallium & $\mu \mathrm{g} / \mathrm{l}$ & 18 & 90 & $<10$ & $<10$ & $<10$ \\
\hline
\end{tabular}




\section{TABLE 6}

ANNUAL INFLUENT AND EFFLUENT WATER QUALITY ANALYSES - CY $1993^{(\text {a) }}$

\begin{tabular}{|c|c|c|c|c|c|c|}
\hline PARAMETER & UNTTS & $\begin{array}{l}\text { CONIINUOUS } \\
\text { CONCENIRATION } \\
\text { GUIDEUNE() }\end{array}$ & $\begin{array}{l}\text { MAXIMUM } \\
\text { CONCENIRATION } \\
\text { GUIDELNE(D) }\end{array}$ & $\begin{array}{l}\text { MUNICIPAL } \\
\text { INFLUENT } \\
\text { WATER }\end{array}$ & $\begin{array}{l}\text { BUL RUN } \\
\text { EFFLUENT }\end{array}$ & $\begin{array}{l}\text { NORTHEAST } \\
\text { AREA } \\
\text { EFFLUENT }\end{array}$ \\
\hline $\begin{array}{l}\text { Volatile Organic Compounds } \\
\text { Bromodichloromethane } \\
\text { Chloroform } \\
\text { Dibromochloromethane }\end{array}$ & $\mu \mathrm{g} / \mathrm{I}$ & $\begin{array}{l}(c)(d) \\
(\theta) \\
389 \\
(\theta)\end{array}$ & $\begin{array}{l}(c)(d) \\
(\theta) \\
1945 \\
(\theta)\end{array}$ & $\begin{array}{l}(c)(d) \\
31 \\
36 \\
19\end{array}$ & $\begin{array}{l}(c)(d) \\
5.0 \\
<5 \\
6.0\end{array}$ & $\begin{array}{l}(c)(d) \\
5.0 \\
<5 \\
6.0\end{array}$ \\
\hline Zinc & $\mu \mathrm{g} / \mathrm{I}$ & $150^{(t)}$ & $165^{(0)}$ & 160 & 220 & 150 \\
\hline
\end{tabular}

N

(a) Additional samples of municipal influent water and Bull Run and Northeast Area effluents were collected as part of the RFI.

(b) Based on the fish and aquatic life criteria provided in Pennsylvania Code, Title 25, Department of Environmental Resources, Chapter 16, Water Quality Toxics Management Strategy. The guidelines are for the Bull Run and Northeast Area effluent and do not apply to sanitary effluent.

(c) The specific guldelines and associated compounds analyzed are identified in Appendix A, Table 1 of Pennsylvania Code, Title 25, Department of Environmental Resources, Chapter 16, Water Quality Toxics Management Strategy. All analysis results were less than the minimum detectable level for the parameter unless otherwise specified.

(d) In some cases, a minimum detectable level which was higher than the guideline was encountered even though the minimum detection level recommended in Pennsylvania Code, Title 25, Department of Environmental Resources, Chapter 16, Water Quality Toxics Management Strategy was achleved. As a result, a direct comparison to the guideline cannot be made; however, these compounds are not believed to be present in the effluent.

(e) No specific guideline avallable.

(f) Guldeline calculated based on a hardness value of $150 \mathrm{mg} / \mathrm{l}$.

(g) A sanitary sewer effluent sample at location SAN-10 was also collected for this parameter, and the result was $3 \mu \mathrm{g} / \mathrm{l}$.

(h) A sanitary sewer effluent sample at location SAN-10 was also collected for this parameter, and the result was $0.6 \mu \mathrm{g} / \mathrm{l}$.

(i) A sanitary sewer effluent sample at location SAN-10 was also collected for this parameter, and the result was $0.3 \mu \mathrm{g} / \mathrm{l}$. 
Water Quality Standards and Chapter 16, Water Quality Toxics Management Strategy.

The results in Tables 5 and 6 indicate that nearly all of the values of water quality parameters for the Site effluents were within the discharge standards and the water quality guidelines promulgated by the Commonwealth of Pennsylvania with a few variances as explained below.

The fecal coliform level in the Bull Run effluent exceeded the guideline on a few occasions. An investigation was conducted and it was determined that the elevated fecal coliform levels may have been caused by construction activity disturbing closely located storm and sanitary sewer piping. This disturbance may have allowed a small amount of sanitary effluent to enter the storm sewer system that discharges to the Bull Run outfall. After the construction activity was terminated, follow-up sampling confirmed that the storm and sanitary sewer systems were operating properly since the fecal coliform levels in the Bull Run effluent returned to normal.

On a few occasions, the temperature of the Bull Run effluent and Northeast Area effluent exceeded the guideline. These elevated temperature levels were attributed primarily to the coincident high temperature of the influent municipal water supply which also exceeded the guideline on several occasions.

The zinc level in the Bull Run effluent (220 $\mu \mathrm{g} / \mathrm{l})$ exceeded the calculated continuous $(150 \mu \mathrm{g} / \mathrm{l})$ and maximum $(165 \mu \mathrm{g} / \mathrm{l})$ concentration guideline. This elevated zinc level was caused primarily by the elevated baseline zinc level $(160 \mu \mathrm{g} / \mathrm{l})$ present in the influent municipal water supply.

The results of analytical laboratory analyses for VOCs in surface water samples collected from on-site and off-site streams and the Bull Run and Northeast Stream monitoring stations confirm the data obtained through historical sampling and analysis. VOCs associated with site operations were not detected in on-site surface water samples collected from the Bull Run and Northeast Stream monitoring stations, the Northeast Stream, or the inactive HTTF drainage channel. VOCs were also not detected in surface water samples collected off-site from Thompson Run Stream. The only surface water samples that contained site-related VOCs were collected from Bull Run Stream downstream of the confluence with Buono and other springs and upstream of the property boundary. VOCs detected in Bull Run Stream included PCE, TCE, and dichloroethylene (DCE).

The presence of VOCs in Bull Run Stream water is due to the continuous discharge of water to the stream from various springs (Buono Spring, RQ-20 Spring, RH Spring) and seeps which contain low levels of PCE; TCE, and DCE. Thus VOC concentrations are likely to remain relatively constant in Bull Run Stream. Based on data obtained, the discharge of low levels of VOCs occurs primarily between Buono Spring and the confluence of the Bull Run Stream and Northeast Stream. The results of surface water sampling and analysis at on-site locations downstream of the Bull Run Stream/Northeast Stream confluence and off-site locations indicate that VOCs in Bull Run Stream surface water are not migrating off-site to a measurable degree.

Sampling and analysis of surface water demonstrated that pesticides (PES), polychlorinated biphenyls (PCBs), and base/neutral and acids (BNAs) are not present at measurable levels.

Based on the above, it was concluded that the water discharged from the Site was of sufficiently high quality that there was no adverse impact on the environment.

\section{B. GROUND WATER}

During 1993, the ground water monitoring program consisted of the collection of water samples from on-site and off-site 
springs and ground water monitoring wells. All of the non-radiological ground water samples were collected as part of the RFI.

The purpose of the ground water monitoring program is to determine the impact of operations on the ground water so that the risk, if any, to human health and the environment can be assessed.

\section{Sources and Treatment}

The potential source of radioactivity and chemical constituents in the site's ground water is from operations conducted in the 1950 s and 1960s. During that time small amounts of radioactivity were released from a few isolated locations on-site as a result of minor breaches in containers and underground pipes containing radioactive materials. In recent years, vigorous efforts to prevent recurrence of these problems have been successful, and much of the soil associated with these past releases has been removed. However, there remain some areas of soil within the Site confines that might release very small amounts of radioactivity from time to time into ground water and subsequently surface water. Monitoring is conducted to detect any influence of this activity on water quality.

The chemical constituents originate from spills or the past practice of on-site disposing of small amounts of spent solvents, typically degreasing agents such as PCE. Since the early 1970 s, these materials have been disposed of off-site.

As part of the 1990 Consent Order under RCRA Section 3008(h), the EPA agreed that current conditions on-site do not require implementation of interim measures (i.e., immediate corrective actions) since site conditions do not present an imminent substantial endangerment to human health or the environment.

\section{Ground Water Monitoring}

The samples and analyses specified below constitute the minimum samples and analyses conducted at the Site during 1993. The well locations and on-site springs are shown on Figure 3.

Radiological: Ground water samples, from springs (on and off-site), selected well locations, and seeps were collected at least annually and analyzed typically for gross alpha, gross beta, radiostrontium and gamma emitters.

Non-Radiological: Ground water samples from wells, springs (on and off-site), and seeps were collected as part of the RFI. Samples were typically analyzed for VOCs, PCBs, BNAs, PESs, Drinking Water Suitability Indicators (arsenic, barium, cadmium, chromium, fluoride, lead, mercury, nitrate as $\mathrm{N}$, selenium, and silver), Ground Water Quality Indicators (chloride, iron, manganese, phenols, sodium, and sulfate), Ground Water Contamination Indicators $(\mathrm{pH}$, specific conductance, total organic carbon, and total organic halogens), and inorganics (antimony beryllium, copper, nickel, thallium, zinc, total cyanide and sulfide).

\section{Ground Water Monitoring Results and Conclusions}

Radiological: The results of the radioactivity analyses for springs and surface water are summarized in Table 7 and the results for monitoring wells are summarized in Table 8.

\section{Springs}

As shown in Table 7, the radioactivity levels in the springs, which are outcrops of the Benwood and Sewickley Sandstone water-bearing zones under the site, were consistent with naturally-occurring radioactivity levels. 


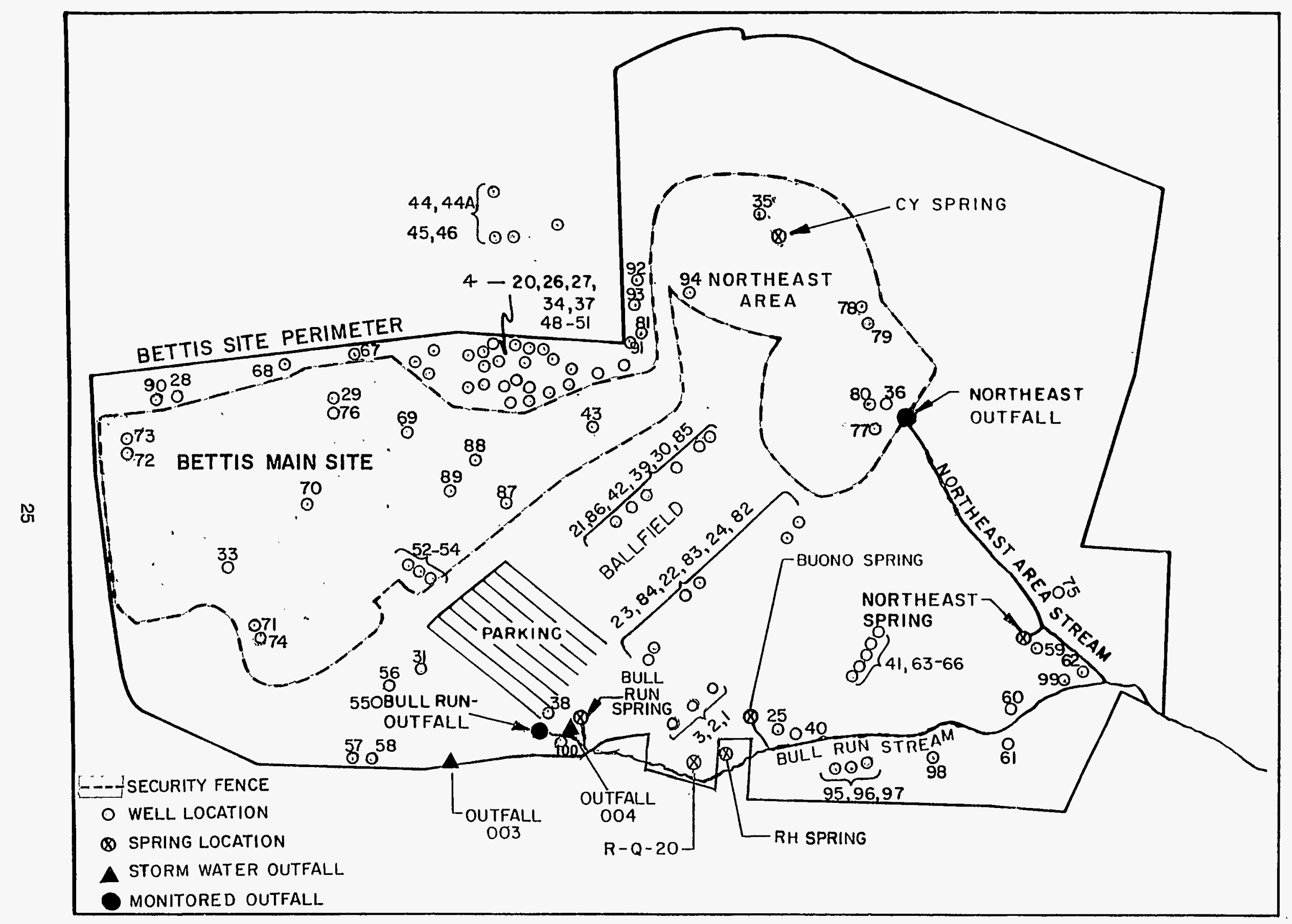

FIGURE 3 LOCATIONS OF WELLS AND SPRINGS 
TABLE 7

SPRING AND SURFACE WATER RADIOACTIVITY RESULTS - 1993

(Units: $10^{-9} \mu \mathrm{Ci} / \mathrm{ml}$ )

\begin{tabular}{|c|c|c|c|c|c|c|c|}
\hline $\begin{array}{c}\text { Sample } \\
\text { Point }\end{array}$ & $\begin{array}{l}\text { Water- } \\
\text { Bearing } \\
\text { Zone }^{(1)}\end{array}$ & $\begin{array}{l}\text { Gross } \\
\text { Alpha }\end{array}$ & $\begin{array}{l}\text { Gross } \\
\text { Beta }\end{array}$ & Sr-90 & Cs-137 & Cs-134 & Co-60 \\
\hline \multicolumn{8}{|c|}{ SPRINGS } \\
\hline Buono Spring & B & $<5.6$ & $<2.3$ & $<0.73$ & $<5.0$ & $<5.6$ & $<5.9$ \\
\hline Buono Spring Stream & B & $<5.8$ & $3.3 \pm 2.9$ & $<0.85$ & $<5.6$ & $<5.6$ & $<6.2$ \\
\hline Buono Spring Stream & B & $<6.3$ & $7.3 \pm 3.2$ & $<0.80$ & $<5.6$ & $<5.8$ & $<6.3$ \\
\hline CY Spring & B & $<4.5$ & $3.3 \pm 2.9$ & $<0.67$ & $<5.2$ & $<5.6$ & $<6.1$ \\
\hline RQ-20 Spring & B & $<4.9$ & $<2.3$ & $<0.78$ & $<6.0$ & $<6.8$ & $<6.6$ \\
\hline RH Spring & $B$ & $<5.1$ & $<2.3$ & $<1.4$ & $<5.2$ & $<5.8$ & $<6.3$ \\
\hline NE Spring & s & $<6.8$ & $5.4 \pm 3.1$ & $<1.3$ & $<5.5$ & $<6.6$ & $<6.4$ \\
\hline Victory Hill Spring ${ }^{(2)}$ & UNR & $<3.3$ & $2.9 \pm 2.8$ & $<2.2$ & $<5.4$ & $<6.2$ & $<5.8$ \\
\hline Gasowski Spring $^{(2)}$ & UNR & $<5.9$ & $7.2 \pm 3.2$ & $<1.3$ & $<5.8$ & $<6.0$ & $<5.4$ \\
\hline Mine Drainage (Curry Hollow) ${ }^{(2)}$ & UNR & $<3.6$ & $14 \pm 3.4$ & $<0.91$ & $<5.2$ & $<6.2$ & $<6.0$ \\
\hline \multicolumn{8}{|c|}{ SURFACE WATER ${ }^{(3)}$} \\
\hline Bull Run Outfall & $N / A$ & $<1.9$ & $<1.8$ & $<1.3$ & $<5.0$ & $<5.6$ & $<5.7$ \\
\hline Northeast Outfall & $N / A$ & $<2.2$ & $2.7 \pm 2.4$ & $<1.2$ & $<5.1$ & $<5.7$ & $<6.0$ \\
\hline Bull Run - Northeast Confluence & $N / A$ & $<3.4$ & $3.0 \pm 2.8$ & $<1.0$ & $<5.0$ & $<5.2$ & $<6.3$ \\
\hline
\end{tabular}

(1) UNR = Offsite water sources unrelated to Bettis water bearing zones.
$\mathrm{N} / \mathrm{A}=$ Not applicable
$B=$ Benwood Water-Bearing Zone

$\mathrm{S}=$ Sewickley Sandstone Water-Bearing Zone

(2) Off-site control springs.

(3) Surface water data presented for comparison purposes. 
TABLE 8

GROUND WATER RADIOACTIVITY RESULTS - 1993

(Units: $10^{-9} \mu \mathrm{Ci} / \mathrm{ml}$ )

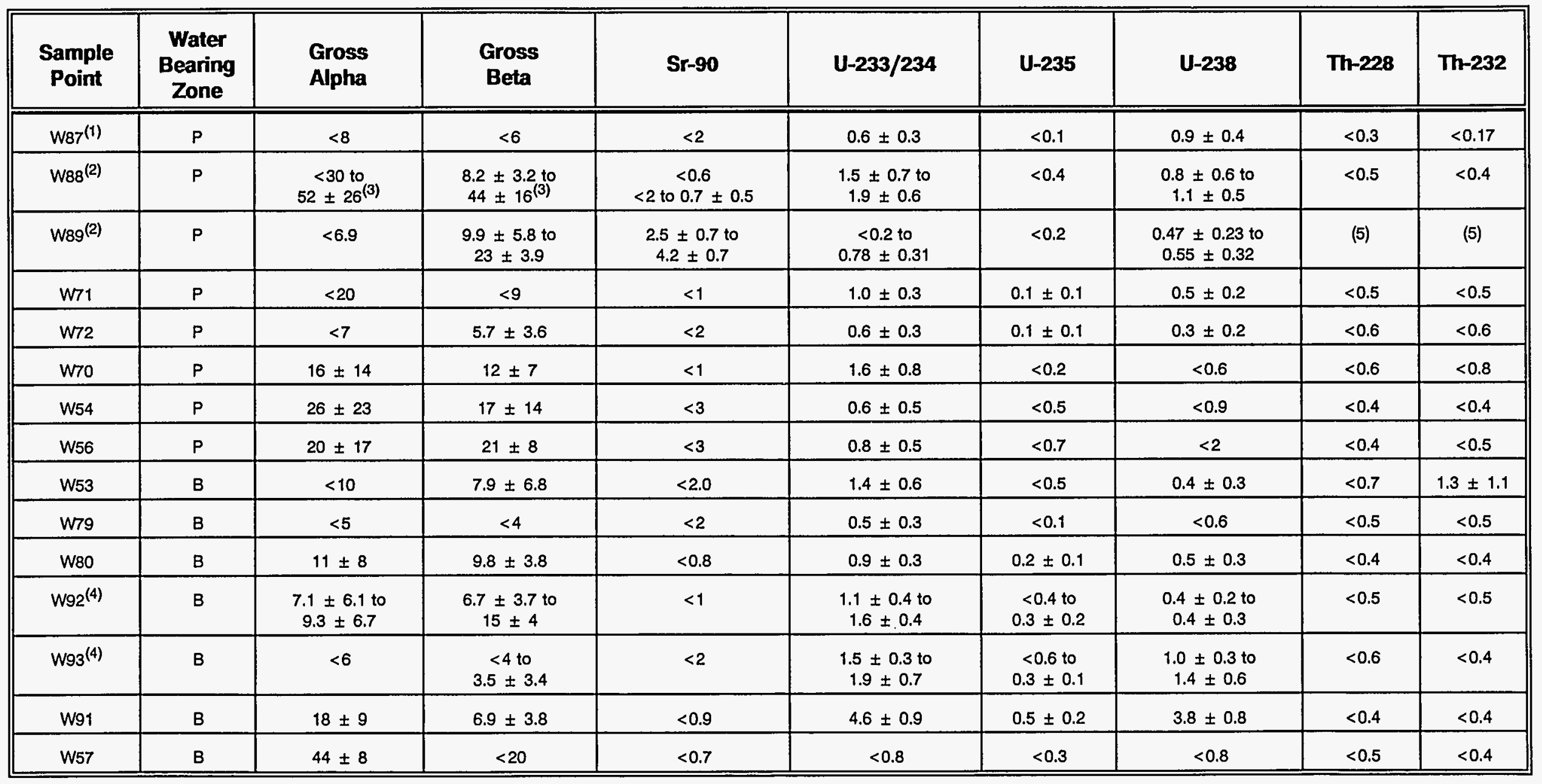


TABLE 8

GROUND WATER RADIOACTIVITY RESULTS - 1993 (Continued)

(Units: $10^{-9} \mu \mathrm{Ci} / \mathrm{ml}$ )

\begin{tabular}{|c|c|c|c|c|c|c|c|c|c|}
\hline $\begin{array}{c}\text { Sample } \\
\text { Point }\end{array}$ & $\begin{array}{c}\text { Water } \\
\text { Bearing } \\
\text { Zone }\end{array}$ & $\begin{array}{l}\text { Gross } \\
\text { Alpha }\end{array}$ & $\begin{array}{l}\text { Gross } \\
\text { Beta }\end{array}$ & Sr-90 & U-233/234 & U-235 & U-238 & Th-228 & Th-232 \\
\hline W55 & B & $39 \pm 22$ & $26 \pm 12$ & $<0.7$ & $0.3 \pm 0.2$ & $<0.4$ & $<0.3$ & $<0.7$ & $<0.7$ \\
\hline W67 & B & $<20$ & $<6$ & $<0.8$ & $<0.5$ & $<0.3$ & $<0.5$ & $<0.7$ & $<0.5$ \\
\hline W68 & B & $<7$ & $19 \pm 5$ & $<1$ & $0.3 \pm 0.2$ & $<0.08$ & $0.3 \pm 0.2$ & $<0.7$ & $<0.7$ \\
\hline W84 & B & $13 \pm 9$ & $10 \pm 4$ & $<2$ & $0.4 \pm 0.2$ & $<0.2$ & $0.3 \pm 0.1$ & $<0.4$ & $<0.5$ \\
\hline W83 & $\mathrm{B}$ & $<4$ & $5.2 \pm 3.4$ & $<0.8$ & $0.5 \pm 0.2$ & $<0.2$ & $0.3 \pm 0.2$ & $<0.5$ & $<0.5$ \\
\hline W85 & B & $<10$ & $29 \pm 10$ & $<1$ & $0.5 \pm 0.2$ & $<0.2$ & $0.3 \pm 0.2$ & $<0.5$ & $<0.5$ \\
\hline W65 & $s$ & $15 \pm 7$ & $6.8 \pm 4.5$ & $<3$ & $0.7 \pm 0.3$ & $<0.3$ & $0.5 \pm 0.3$ & $<0.6$ & $1.3 \pm 1.0$ \\
\hline W77 & $s$ & $76 \pm 25^{(1)}$ & $70 \pm 10^{(1)}$ & $<0.9$ & $4.2 \pm 1.0$ & $1.2 \pm 0.5$ & $2.7 \pm 0.8$ & $0.7 \pm 0.6$ & $0.8 \pm 0.6$ \\
\hline W66 & $s$ & $5.6 \pm 5.1$ & $3.3 \pm 2.6$ & $<2$ & $0.4 \pm 0.2$ & $<0.1$ & $0.2 \pm 0.1$ & $<0.5$ & $<0.7$ \\
\hline W51 & $s$ & $11 \pm 8$ & $9.4 \pm 3.8$ & $<2$ & $2.0 \pm 0.5$ & $0.1 \pm 0.1$ & $1.6 \pm 0.4$ & $<0.5$ & $<0.6$ \\
\hline W60 & PS & $<4$ & $4.3 \pm 3.4$ & $<2$ & $0.3 \pm 0.1$ & $<0.2$ & $<0.3$ & $0.91 \pm 1.0$ & $<0.7$ \\
\hline W61 & PS & $<4$ & $4.0 \pm 3.4$ & $<0.9$ & $<1$ & $<1$ & $<2$ & $<0.7$ & $<0.8$ \\
\hline W75 & PS & $11 \pm 7$ & $12 \pm 4$ & $<2$ & $<0.6$ & $<0.6$ & $<0.6$ & $<0.6$ & $<0.7$ \\
\hline W46 & PS & $<2.7$ & $<2.0$ & $<0.8$ & $0.56 \pm 0.16$ & $<0.05$ & $0.26 \pm 0.11$ & (5) & (5) \\
\hline W52 & $\mathrm{C}$ & $<20$ & $19 \pm 11$ & $<0.9$ & $0.9 \pm 0.5$ & $<0.7$ & $1.0 \pm 0.5$ & $<0.4$ & $0.7 \pm 0.6$ \\
\hline W63 & C & $23 \pm 10$ & $16 \pm 4$ & $<0.8$ & $0.6 \pm 0.3$ & $0.09 \pm 0.07$ & $0.4 \pm 0.1$ & $<0.4$ & $<0.4$ \\
\hline W44 & $C$ & $<4$ & $9.1 \pm 3.8$ & $<0.9$ & $<0.3$ & $<0.2$ & $<0.3$ & $<0.4$ & $<0.4$ \\
\hline W44A & c & $<4$ & $7.1 \pm 3.7$ & $<0.7$ & $8.5 \pm 1.2$ & $0.3 \pm 0.1$ & $7.4 \pm 1.1$ & $<0.3$ & $<0.3$ \\
\hline
\end{tabular}


TABLE 8

GROUND WATER RADIOACTIVITY RESULTS - 1993 (Continued)

(Units: $10^{-9} \mu \mathrm{Ci} / \mathrm{ml}$ )

\begin{tabular}{||c|c|c|c|c|c|c|c|c|c|}
\hline $\begin{array}{c}\text { Sample } \\
\text { Point }\end{array}$ & $\begin{array}{c}\text { Water } \\
\text { Bearing } \\
\text { Zone }\end{array}$ & $\begin{array}{c}\text { Gross } \\
\text { Alpha }\end{array}$ & $\begin{array}{c}\text { Gross } \\
\text { Beta }\end{array}$ & Sr-90 & U-233/234 & U-235 & U-238 & Th-228 & Th-232 \\
\hline \hline W45 & $\mathrm{C}$ & $<2.3$ & $<1.9$ & $<0.4$ & $0.23 \pm 0.13$ & $<0.08$ & $<0.09$ & $(5)$ & $(5)$ \\
\hline W48 & $\mathrm{C}$ & $8.8 \pm 7.2$ & $9.7 \pm 3.8$ & $<3$ & $0.7 \pm 0.2$ & $<0.04$ & $0.4 \pm 0.2$ & $<0.6$ & $<0.7$ \\
\hline
\end{tabular}

Water Bearing Zones: $\quad \begin{aligned} & \mathrm{P}=\text { Perched Water-Bearing Zone } \\ & \mathrm{B}=\text { Benwood Water-Bearing Zone }\end{aligned}$

$\mathrm{S}=$ Sewickley Sandstone Water-Bearing Zone
$P=$ Pittsburgh Sandstone Water-Bearing Zone

$\mathrm{C}=$ Pittsburgh Coal Water-Bearing Zone

1. Ranges based on results from 4 samples per location for gross alpha, gross beta and Sr-90. Single MDL values indicate maximum results for 4 samples. Uranium and Thorium results based upon single sample.

2. Ranges based on results from 4 samples for gross alpha, gross beta and Sr-90. Uranium and Thorlum results based upon 2 samples and single MDL values indicate maximum results for 2 samples.

3. An aliquot of the water sample was filtered through a $0.45 \mu$ filter and the filtrate analyzed for gross alpha and gross beta activity. The results were $<20 \times 10^{-9} \mu \mathrm{Ci} / \mathrm{ml}$ and $<20 \times 10^{-\theta} \mu \mathrm{Ci} / \mathrm{ml}$ respectively.

4. Ranges based on 2 samples for all analyses. Single MDL values indicate maximum results for 2 samples.

5. Data unavailable. 
Monitoring Wells

Table 8 presents the radioactivity data for the ground water monitoring wells which were installed as part of the RFI and monitored in 1993. These wells monitor the five water-bearing zones down to and including the Pittsburgh coal seam under the site. These water-bearing zones are illustrated and discussed in detail in the Draft RFI Report (Reference (1)).

The radioactivity data for the Perched water-bearing zone are consistent with natural background levels of radioactivity in ground water in this area with the exception of Well 89 and the possible exceptions of Wells 87 and 88 . Well 89 contains low-level, Bettis-generated Strontium-90 that probably originated in the soil under the Materials Evaluation Laboratory (MEL). The maximum level of $\mathrm{Sr}-90$ measured was $4.2 \times 10^{-9} \mathrm{uCi} / \mathrm{ml}$, which is less than $1 \%$ of the limit of Reference (5) for Sr-90 in water in unrestricted areas. The first three samples of Wells 87 and 88 did not contain any measurable levels of Sr-90. The last samples collected in 1993 appear to contain trace levels (i.e., $0.7 \pm 0.5 \times 10^{-9}$ $\mathrm{uCi} / \mathrm{ml}$ ) but the uncertainties are very high. The abnormal gross alpha and gross beta results for the March sample from Well 88 are attributed to the presence of suspended solids in the sample. This is common for newly installed wells; as wells are purged prior to subsequent sampling, the suspended solids decrease with a concurrent decrease in the values of the gross alpha and beta analyses.

Subsequent sample results for Well 88 show the decrease in the gross activity levels to normal background levels. The radioactivity data for the Benwood waterbearing zone are consistent with natural levels of radioactivity in ground water in this area with the possible exception of Well 91. Ground water in Well 91, located on the Inactive Waste Site (IWS), may contain slightly elevated levels of natural uranium. The low levels (U-233/234, 4.6 $\times 10^{-9} \mathrm{uCi} / \mathrm{ml} ; \mathrm{U}-235,0.5 \times 10^{-9} \mathrm{uCi} / \mathrm{ml} ; \mathrm{U}-$ $238,3.8 \times 10^{-9} \mathrm{uCi} / \mathrm{ml}$ ) are less than $2 \%$ of the limits of Reference (5) for these radionuclides in water in unrestricted areas.

The radioactivity data for three of the four wells sampled from the Sewickley Sandstone water-bearing zone are consistent with natural levels of radioactivity in ground water. The gross alpha $\left(7.6 \times 10^{-8} \mathrm{uCi} / \mathrm{ml}\right)$ and gross beta $\left(7.0 \times 10^{-8} \mathrm{uCi} / \mathrm{ml}\right)$ data for Well 77 are above typical background levels of radioactivity but consistent with the levels of natural uranium. The absence of Sr-90 and other fission products demonstrates the absence of any significant levels of Bettis-generated radioactivity.

The radioactivity data for the wells monitoring the Pittsburgh Sandstone water-bearing zone are consistent with background levels of radioactivity.

The radioactivity data for the wells monitoring the Pittsburgh Coal waterbearing zone are consistent with background levels of radioactivity with the exception of Well 44A, which is located downgradient of the IWS on WWSC property. Well 44A water shows low levels of natural uranium and are less than $3 \%$ of Reference (5) for these radionuclides in water in unrestricted areas. Well 44, located a few feet from $44 \mathrm{~A}$ and installed in the same ground water zone, does not show enhanced levels of natural uranium. During 1992, the results for both Wells 44 and $44 \mathrm{~A}$ did not indicate the presence of natural uranium above normal background levels.

With the exception of a small area of perched water south of the MEL which contains very low levels of Sr-90 and a few wells which show low levels of natural uranium, the vast majority of ground water in the five water-bearing regions under the site do not contain any Bettis-generated radioactivity. 


\section{Inactive Waste Site Seepage and Runoff}

Samples of IWS seepage and runoff were collected in March, 1993. The radioactivity data show the presence of low levels of natural uranium which is consistent with previous data for the seepage and runoff. The maximum levels of gross radioactivity were measured from the northern most IWS access roadway subsurface drain at $4.6 \times 10^{-7} \mathrm{uCi} / \mathrm{ml}$ alpha and $2.0 \times 10^{-7}$ $\mathrm{uCi} / \mathrm{ml}$ beta-gamma. The levels of uranium were U-233/234, $1.3 \times 10^{-7}$ $\mathrm{uCi} / \mathrm{ml} ; \mathrm{U}-235,5.9 \times 10^{-9} \mathrm{uCi} / \mathrm{ml}$; and $\mathrm{U}$ $238,1.3 \times 10^{-9} \mathrm{uCi} / \mathrm{ml}$. At location 06 , the levels were $8.0 \times 10^{-9} \mathrm{uCi} / \mathrm{ml}, 0.8 \times 10^{-9}$ $\mathrm{uCi} / \mathrm{ml}$ and $7.2 \times 10^{-9} \mathrm{uCi} / \mathrm{ml}$, respectively; these measurements are also consistent with previous measurements.

The concentrations of radionculides detected in off-site runoff were well below their Reference (5) limits for water in unrestricted areas. Based on the concentrations of the radionuclides and the fact that the ditch water is not consumed by humans, the presence of these low levels of radioactivity in the runoff does not pose a threat to human health.

Non-Radiological: The results of the analyses of ground water for nonradiological chemical constituents are presented in detail in the Draft RFI Report that was submitted to the EPA in December, 1993. The results are summarized below:

Chemical constituents in ground water are evident in the Perched, Benwood, Sewickley Sandstone water-bearing zones and, to a much smaller degree, in the Pittsburgh Sandstone water-bearing zone. Ground water data from wells in the Pittsburgh Coal do not show evidence of ground water constituents associated with operations at the Site. The results, which confirmed previous data, established that the primary contaminants of concern are PCE, TCE, and DCE. The average total VOC levels in the water-bearing zones are as follows: Perched $-0.1 \mathrm{mg} / \mathrm{l}$; Benwood -
$1.3 \mathrm{mg} / \mathrm{l}$; Sewickley Sandstone $-5.9 \mathrm{mg} / \mathrm{l}$; Pittsburgh Sandstone $-0.065 \mathrm{mg} / \mathrm{l}$. No evidence was noted of lateral off-site migration of contaminants in any of the water-bearing zones.

The runoff from the IWS also contained the same VOCs as described above. The maximum level of PCE, the most prevalent of the VOCs, was $0.15 \mathrm{mg} / \mathrm{l}$. Low levels $(0.007 \mathrm{mg} / \mathrm{l})$ of PCBs were detected in two of six runoff samples.

\section{AIRBORNE EFFLUENTS}

The purpose of the airborne effluent monitoring program is to determine the effectiveness of control methods, measure concentrations in effluents for comparison with applicable standards and natural background levels, and to assess the effect of any inadvertent releases to the environment.

\section{Sources and Treatment}

All areas of the Site wherein unencapsulated radioactive materials were handled were equipped with wet scrubbers or filtered exhaust systems. The high efficiency particulate air (HEPA) filters were preceded as necessary by prefilters to remove dust and large particulates. Charcoal filters were installed in select air handling systems to control gaseous radioactivity releases. HEPA filters were tested upon installation and at least annually thereafter to assure that high removal efficiencies (99.95\%) are maintained.

Sources of airborne effluents not related to radiological operations were heating systems, such as boilers and space heaters which use combustible gas and oil, and small scale operations involving chemicals. Fuel-burning and combustion equipment and $\mathrm{RFI}$ vapor extraction pilot tests at the Site were operated in compliance with their Allegheny County Air Pollution Operating and Installation

Permits. 


\section{Airborne Monitoring}

The samples and analyses specified below constitute the minimum samples and analyses conducted at the Site during 1993.

All radioactive airborne effluents from the Site were continuously monitored using fixed-filter air stations operated at a constant, metered flow rate under isokinetic sampling conditions. Particulate radioactivity in the effluents was collected on a 0.8 micron Millipore filter. Gaseous radionuclides, primarily lodine-131 and Antimony-125, from relevant stacks were collected on a charcoal impregnated filter. Filters were collected and analyzed at least weekly for gross alpha and gross beta radioactivity with the exception of the filter from an inactive L-Building facility which is collected and analyzed quarterly. Additionally, the charcoal filters were analyzed for gamma emitters. Quarterly, the particulate filters from each exhaust were composited and analyzed for gross alpha and gross beta radioactivity. The composites were also analyzed for gamma emitters. Select filters were analyzed for Strontium-89, -90. In addition, sampling for the short half-life (55 seconds) Radon220 from thorium handling areas was performed annually using a filter and charcoal cold-trap method. The Site's radiological exhaust monitoring systems are in compliance with the EPA's requirements in Reference (7).

Air in the environment remote from the Site was monitored continuously using two fixed-filter air samplers positioned off-site at Large, PA and West Mifflin, PA which are approximately 5 miles and 1.5 miles, respectively, from the Site. The sampling station at Large is in a generally upwind location from the Site and the West Mifflin station is in a generally downwind direction. Environmental air filters were collected and analyzed weekly for gross alpha and gross beta radioactivity.

There were no major chemical operations at the Site during 1993 which might contribute significant quantities of nonradioactive airborne pollutants. Estimates of particulate and gaseous emissions for systems involving nonradioactive materials were used to ensure that applicable standards were met.

\section{Airborne Analyses}

The radioanalytical techniques employed were sufficiently sensitive to measure radioactivity below background radioactivity levels of the air in the Pittsburgh Metropolitan Area. It was conservatively assumed for airborne effluents which were below minimum detection levels that the exhaust air contained radioactivity at the minimum detection level. Although comparisons of the Site's airborne effluent results were made to the background radioactivity levels measured at remote off-site locations no background corrections were made to the Site's release results.

The sample particulate filters were analyzed for alphia and beta radioactivity at approximately 48 hours after collection to permit the decay of the natural airborne, short-lived radon-thoron daughter products accumulated on the filters. The alpha and beta radioactivities were measured using a lead-shielded, gas-flow proportional counter. If any weekly or semi-weekly sample result were to exceed half of the concentration guide for airborne radioactivity in uncontrolled regions (Reference (5)), the stack sample would be analyzed for specific radionuclides, the cause of the release of radioactivity would be identified, and actions would be taken to reduce the amount of radioactivity released to as low as practicable.

The sample filters from each exhaust area were composited and analyzed quarterly for alpha and beta radioactivity as described above as well as analyzed for gamma emitters. The results of these analyses were used to provide a record of the long-lived particulate radioactivity releases from the Site. Any sample composite result exceeding alpha or beta 
radioactivity levels of $2.0 \times 10^{-14} \mu \mathrm{Ci} / \mathrm{ml}$ was investigated. This level is the most restrictive concentration guide that exists for any single radionuclide in air which decays by alpha emission or spontaneous fission and it is also well below the most restrictive concentration guide for any beta and gamma-emitting radionuclide that is present in radiological operations or in the environment (Reference (5)). Gamma analyses were conducted using a high resolution $\mathrm{Ge}(\mathrm{Li})$ or germanium detector and a multichannel analyzer. A typical minimum detection level for Cesium-137 was $5.0 \times 10^{-16} \mu \mathrm{Ci} / \mathrm{ml}$. Alpha spectrometry was performed using a solid state silicon surface barrier detector and a multichannel analyzer after elemental separation and mount preparation. In addition, radiostrontium analyses were performed on selected quarterly filter composites from potential source areas. A typical minimum detection level for Strontium-90 was $0.8 \times 10^{-15} \mu \mathrm{Ci} / \mathrm{ml}$.

The charcoal impregnated air filters were analyzed weekly for alpha and beta radioactivity and for specific gamma emitting radionuclides. Gamma analyses were performed using a $\mathrm{Ge}(\mathrm{Li})$ gamma spectrometry system. A typical minimum detection level for gaseous lodine-131 was $2.0 \times 10^{-14} \mu \mathrm{Ci} / \mathrm{ml}$.

The charcoal filters used for measuring Radon-220 releases were analyzed using the high resolution $\mathrm{Ge}(\mathrm{Li})$ detector. The Radon-220 concentrations were determined from the characteristic photopeak of Lead-212 which is the principal gamma emitting product of Radon-220 decay.

\section{Airborne Monitoring}

\section{Results and Conclusions}

Radiological: The results of the monitoring of particulate and gaseous radioactivity effluents from the Site during 1993 are summarized in Table 9 . Specific results from air effluent monitoring are discussed below.
The total airborne particulate and gaseous radioactivity released from the Site during 1993, with radionuclide decay half-lives greater than one day, was less than $1.2 x$ $10^{-5}$ Curie. The average concentration of airborne particulate gross alpha radioactivity released during 1993 was less that $8.73 \times 10^{-16} \mu \mathrm{Ci} / \mathrm{ml}$ and the average concentration of airborne particulate gross beta radioactivity was less than $3.87 \times 10^{-15}$ $\mu \mathrm{Ci} / \mathrm{ml}$. These concentrations are well below $1 \%$ of the most restrictive concentration guide given in Reference (5) for Thorium-232 and Strontium-90 in air of uncontrolled areas.

By comparison, the average gross alpha and gross beta particulate airborne radioactivity measured for environmental air at the off-site locations was $1.4 \times 10^{-15}$ $\mu \mathrm{Ci} / \mathrm{ml}$ and $2.6 \times 10^{-14} \mu \mathrm{Ci} / \mathrm{ml}$, respectively. Thus, on the average, the gross alpha and gross beta radioactivity concentrations in air emitted from the Site were 1.6 and 6 times, respectively, less than background radioactivity levels in environmental air due to the Site's filtration systems.

The primary contributor to the long-lived (greater than one day half-life) gaseous radioactivity released was Antimony-125 which has a half-life of 2.7 years.

Antimony-125 was released at an average concentration of less than $2.10 \times 10^{-14}$ $\mu \mathrm{Ci} / \mathrm{ml}$ which is $0.003 \%$ of the limit for the maximum radioactivity concentration permitted for air in uncontrolled areas given in Reference (5). Release data for other gaseous radioactivity, as compared to their respective limits, are shown in Table 9. 
TABLE 9

\section{SUMMARY OF RADIOACTIVITY IN AIRBORNE EFFLUENTS CY 1993}

\begin{tabular}{||l|c|c|c|c||}
\hline \multicolumn{1}{|c|}{ Activity } & $\begin{array}{c}\text { Total } \\
\text { Activity } \\
(\mu \mathrm{Ci})\end{array}$ & $\begin{array}{c}\text { Average } \\
\text { Concentration } \\
(\mu \mathrm{Ci} / \mathrm{ml})\end{array}$ & $\begin{array}{c}\text { Limit } \\
(\mu \mathrm{Ci} / \mathrm{ml})\end{array}$ & \% of Limit \\
\hline \hline Alpha & $\leq 0.84$ & $\leq 9.48 \times 10^{-18}$ & $4.0 \times 10^{-15(2)}$ & 23.7 \\
\hline Beta & $\leq 4.07$ & $\leq 4.58 \times 10^{-15}$ & $3.0 \times 10^{-11(3)}$ & 0.015 \\
\hline Sb-125 & $\leq 3.43$ & $\leq 2.10 \times 10^{-14}$ & $7.0 \times 10^{-10}$ & 0.003 \\
\hline I-131 & $\leq 2.92$ & $\leq 1.8 \times 10^{-14}$ & $2.0 \times 10^{-10}$ & 0.009 \\
\hline Pu-238 & $\leq 9.55 \times 10^{-3}$ & $\leq 3.59 \times 10^{-16}$ & $2.0 \times 10^{-14}$ & 1.79 \\
\hline Eu-152 & $\leq 1.82 \times 10^{-2}$ & $\leq 1.67 \times 10^{-15}$ & $3.0 \times 10^{-11}$ & 0.006 \\
\hline U-233 & $\leq 1.20 \times 10^{-2}$ & $\leq 4.70 \times 10^{-17}$ & $5.0 \times 10^{-14}$ & 0.094 \\
\hline Cs-137 & $\leq 1.27 \times 10^{-14}$ & $\leq 6.76 \times 10^{-16}$ & $2.0 \times 10^{-10}$ & $3.38 \times 10^{-4}$ \\
\hline
\end{tabular}

Total Particulate Radioactivity: $\leq 5.1 \times 10^{-6}$ Curies

Total Gaseous Radioactivity: $\leq 6.4 \times 10^{-6}$ Curies $^{(4)}$

(1) NRC limit as prescribed in Title 10, Code of Federal Regulations, Part 20 for air in uncontrolled regions.

(2) Based on Th-232

(3) Based on Sr-90

(4) Gaseous radioactivity with radionuclide decay half-lives greater than one day. 
All gaseous radioactivity concentrations were small fractions of the applicable limits.

Based on the results of Radon-220 effluent measurements and pathway evaluations, the average concentration of the releases at the site boundary was estimated to be approximately $2.5 \times 10^{-11} \mu \mathrm{Ci} / \mathrm{ml}$. This level is below the concentration guide of $3.0 \times 10^{-11} \mu \mathrm{Ci} / \mathrm{ml}$ for Radon-220 in the air of uncontrolled areas. The releases of the very short-lived (55 seconds) Radon-220 gaseous radioactivity from the Site resulted in no adverse effect on the surrounding environment and did not result in radiation exposures above the EPA and DOE radiation dose standards, as shown in Table 14 of Section I.

The results of the Site's airborne radiological effluent monitoring for 1993 have shown that the amount of airborne radioactivity released was too small to result in any measurable change in the background radioactivity levels in the environment. The concentrations of the particulate and gaseous radioactivity released from the Site during 1993 were below the applicable standards for radioactivity in environmental air.

Furthermore, the estimated radiation dose to any member of the public from the airborne radioactivity released was too low to measure and was significantly below the radiation protection standards established by the EPA in Reference (7).

Non-radiological: The results of evaluations and calculations for the Site's sources of airborne pollutants from areas where no radioactive materials were involved are summarized below:

\section{(1) Heating System Exhaust}

The boilers and space heating systems at the Site were fueled with natural gas and No. 2 distillate fuel oil. The heating systems were operated in accordance with their Allegheny County Air Pollution Source Operating Permits. Conservative estimates of the pollutant releases utilizing EPA emission factors, based on the actual fuel usage of the heating systems and fuel type, were made. These calculations show that the airborne emissions from the Site's heating systems are well below the applicable local discharge limits identified in Reference (8).

\section{(2) Exhausts from Site Fume Hoods}

Chemical vapors collected by the Site's fume hoods are similar to those from other research labs engaged in analytical chemistry and development efforts. Air exhausted from the Site's fume hoods was treated, as required, by filtration or wet scrubbers to minimize the release of such materials. On the basis of the small scale of the operations, the type of material handled, and the treatment provided, it was concluded that the Site fume hood exhausts did not have any adverse effect on the environment.

\section{(3) Asbestos Removal Work}

All asbestos removal work was completed in compliance with the requirements of 40 CFR 61 Subpart $M$ and Section 1001, Chapter X, Article XX, Air Pollution Control, Allegheny County Health Department (ACHD) to limit the discharge of asbestos fibers to the environment.

\section{(4) Chemically Contaminated Areas}

As part of the RFI, air samples were taken at the IWS and the Bettis Landfill (BL) for airborne asbestos and PCBs. The results of analytical laboratory analyses for air monitoring samples collected from the IWS and BL confirm the data obtained through historical air monitoring and sampling that airborne asbestos is not being released at the IWS or BL.

The PCB data obtained during the second round of sampling do not conclusively verify the absence or 
presence of airborne PCBs. Results of the first round of sampling and the results of personnel sampling did not indicate the presence of any airborne PCBs. It is judged that the IWS and BL are not sources of airborne PCBs based on RFI and pre-RFI airborne monitoring data, and the low concentrations and sparse distribution of PCBs at these areas.

Organic vapor monitoring of the ground surface was also conducted at both the IWS and BL. This monitoring did not detect the release of organic vapors at either location.

The analytical results and an interpretation of the significance is contained in the Draft RFI Report submitted to the regulatory agencies in December 1993.

In addition, the results of exhaust monitoring from the vapor extraction pilot tests conducted at the IWS and BL during the RFI indicated that the systems were operated in compliance with their Allegheny County Air Pollution Source Installation Permits. The results of the air monitoring conducted during the pilot vapor extraction tests was provided to the EPA in the Remedial Technologies Studies report which accompanied the Draft RFI Report. Reports on the emissions were also submitted to the ACHD.

\section{STREAM SEDIMENT, SOIL AND VEGETATION}

The purpose of the stream sediment, soil and vegetation monitoring program is to determine if any long-term buildup of radioactivity or chemicals is occurring in the sediment and the vegetation in and along the site's effluent streambeds.

\section{Sources}

Surface or ground water flows containing residual radioactivity or chemicals from past operations could deposit these materials in the soil.

\section{Sediment, Soil and Vegetation Monitoring}

Radiological: Routine sediment samples were collected semiannually from the streambeds of the site's effluent streams and from an off-site control stream, as shown in Figure 4. Six sediment samples were collected along the length of Bull Run and Thompson Run. One sample each was collected from the Northeast Area effluent stream, Buono Spring and the control stream at Streets Run. The control stream at Streets Run is remote from the Site and there are no known nuclear or radiological facilities in operation which release radioactive waste effluents to the control stream.

Vegetation growing in and along the Site's effluent streams, Buono Spring and from an off-site control stream was collected at the same locations as the routine sediment collection locations. Vegetation samples were also collected at locations outside of streams and floodplains.

In addition, two on-site manholes and the catch basins at the Bull Run and Northeast Area monitoring stations were sampled for sediment at least annually if sediment was available. 


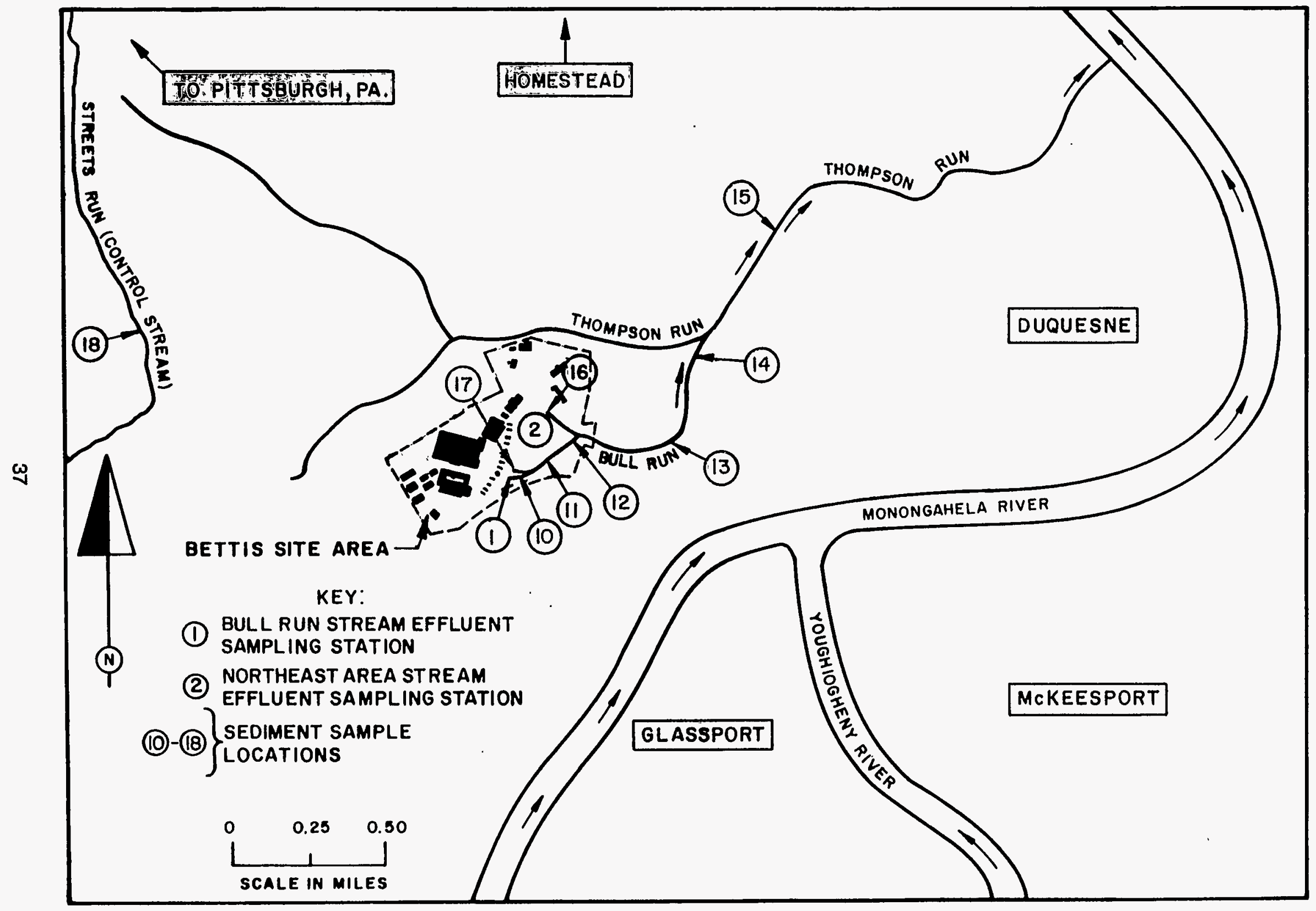

FIGURE 4 SEDIMENT AND VEGETATION MONITORING LOCATIONS 
Duplicate aliquots of sediment samples were analyzed for gross alpha and gross beta radioactivity. Single aliquots were analyzed for Strontium-89 and -90 , and gamma emitters. The vegetation samples were analyzed for Strontium-89 and -90 activity and gamma emitters.

Non-Radiological: Some soil samples were collected prior to proposed excavation and construction activities. However, most of the non-radiological soil and sediment samples were collected as part of the RFI.

\section{Sediment, Soil and Vegetation Analyses}

Radiological: The sediment samples were oven-dried, milled, homogenized, and screened to remove large stones and extraneous materials. The vegetation samples were air dried, chipped, and blended. The homogenized samples were uniformly distributed on a planchet for alpha and beta counting. The alpha and beta radioactivities were measured by counting the dried samples using a lead shielded, gas-flow proportional counter. Gamma analyses were performed on the sediment and vegetation by counting the dried samples with a gamma spectrometry system. Typical minimum detectable concentrations for the gamma analyses ranged from $0.03 \times 10^{-6}$ to $0.09 \times$ $10^{-6} \mu \mathrm{Ci} / \mathrm{gm}$ for sediment and $0.09 \times 10^{-6}$ to $0.36 \times 10^{-6} \mu \mathrm{Ci} / \mathrm{gm}$ for vegetation samples depending on sample size, counting time, and gamma ray energy.

Radiostrontium analyses of the samples were performed utilizing a standard strontium radiochemical procedure. The strontium was chemically separated and the sample was counted for beta radioactivity using the low background proportional counter described above. Typical minimum detectable concentrations for Strontium-90 ranged from $0.1 \times 10^{-6}$ to $0.6 \times 10^{-6} \mu \mathrm{Ci} / \mathrm{gm}$ depending on sample size and chemical yield.

Non-Radiological: The sediments and soils were analyzed by an off-site vendor using EPA approved methods.
Sediment, Soil, and Vegetation Monitoring Results and Conclusions

Radiological: The results of environmental radioactivity analyses of sediments and vegetation collected during 1993 from the site effluent streams and off-site control stream are summarized in Tables 10, 11, and 12 , respectively.

The alpha radioactivity levels in the Bull Run/Thompson Run streams, the Northeast Area stream and the Buono Spring sediment samples were consistent with the alpha radioactivity levels in the control stream sediment.

The beta radioactivity levels in the Bull Run/Thompson Run streams, Northeast Area stream and the Buono Spring sediment samples were consistent with the beta radioactivity levels in the control stream sediment.

The low levels of Cesium-137 radioactivity, $0.23 \times 10^{-6} \mu \mathrm{Ci} / \mathrm{g}$ to $3.6 \times 10^{-6} \mu \mathrm{Ci} / \mathrm{g}$, detected in the sediment of the routine samples from the Bull Run and Thompson Run Streams are due to residual radioactivity from effluent releases which occurred more than 25 years ago. The levels identified in 1993 are consistent with levels detected in past years and compare with gamma radioactivity concentrations typically found in soil of approximately $20 \mathrm{x}$ $10^{-6} \mu \mathrm{Ci} / \mathrm{g}$.

Cesium -137 radioactivity ranging from $0.076 \times 10^{-6}$ to $0.17 \times 10^{-6} \mu \mathrm{Ci} /$ gram was detected in the Northeast Area Stream and Buono Spring sediment. Based on past operations, historical radioactivity releases were not conducted in these areas and the very low levels are most likely due to atmospheric fallout.

The radioactivity levels for Cesium-134, Cobalt-60, Strontium-89 and Strontium-90 in the sediment from the Bull Run, Thompson Run, and the Northeast Area Streams and the Buono Spring were below minimum detection levels and were consistent with the levels in the control stream sediment. 
TABLE 10

STREAM SEDIMENT RADIOACTIVITY ANALYSES, CY 1993

Range of Concentrations ${ }^{(1,2)}, \times 10^{-6} \mu \mathrm{Ci} / \mathrm{gm}$ dry weight

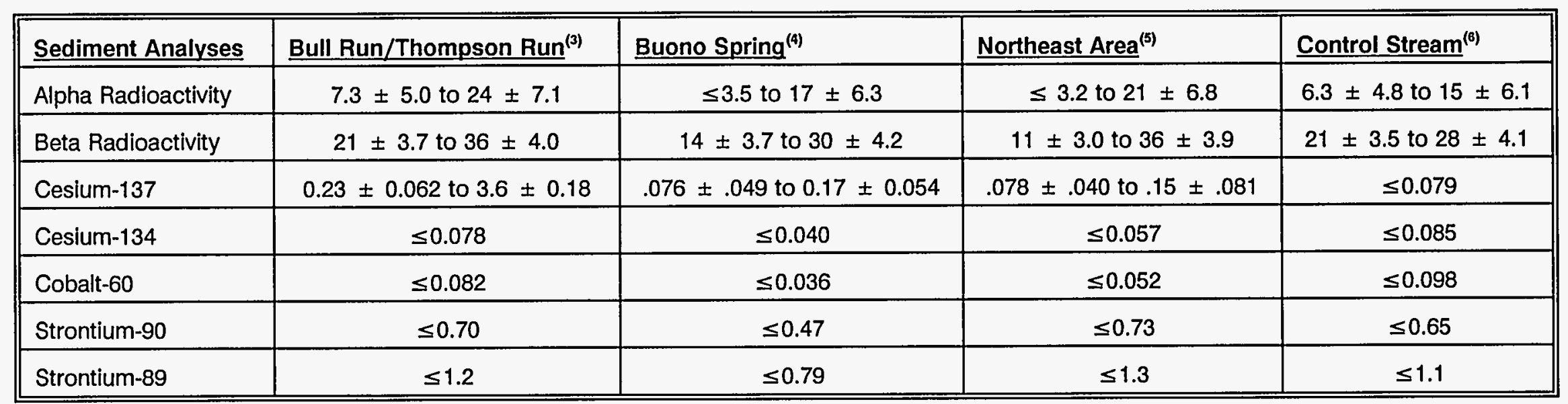

(1) Uncertainties are based on counting statistics at the $95 \%$ confidence level.

(2) $\leq$ signifies at or below the minimum detection level (MDL).

(3) Ranges are for 15 samples. Single MDL values indicate the maximum MDL result for the 15 samples.

(4) Ranges are for 2 samples. Single MDL values indicate the maximum MDL result for the 2 samples.

(5) Ranges are for 3 samples. Single MDL values indicate the maximum MDL result for the 3 samples.

(6) Ranges are for 2 samples. Single MDL values indicate the maximum MDL result for the 2 samples. 
TABLE 11

\section{STREAM VEGETATION RADIOACTIVITY ANALYSES, CY 1993 Range of Concentrations ${ }^{(1,2)}, \times 10^{-6} \mu \mathrm{Ci} / \mathrm{gm}$}

\begin{tabular}{||l|c|c|c|c||}
\hline Vegetation Analyses & Bull Run/Thompson Run & \\
& $(3)$ & Buono Spring $^{(4)}$ & Northeast Area $^{(4)}$ & Control Stream $^{(4)}$ \\
\hline Strontium-89 & $\leq 0.082$ & $\leq 0.032$ & $\leq 0.32$ & $\leq 0.050$ \\
\hline Strontium-90 & $<0.016$ to $0.072 \pm 0.027$ & $\leq 0.014$ & $0.059 \pm 0.024$ & $\leq 0.022$ \\
\hline Cesium-137 & $\leq 0.028$ & $\leq 0.0099$ & $\leq 0.033$ & $\leq 0.013$ \\
\hline Cesium-134 & $\leq 0.030$ & $\leq 0.011$ & $\leq 0.036$ & $\leq 0.016$ \\
\hline Cobalt-60 & $\leq 0.035$ & $\leq 0.012$ & $\leq 0.038$ & $\leq 0.015$ \\
\hline
\end{tabular}

(1) Uncertainties are based on counting statistics at the 95\% confidence level.

(2) $\leq$ signifies at or below the minimum detection level (MDL).

(3) Ranges are for 7 stream samples. Single MDL values indicate the maximum MDL result for the 7 stream samples.

(4) Single samples of stream vegetation were collected for these locations. 
TABLE 12

\section{VEGETATION RADIOACTIVITY ANALYSES, CY $1993^{(1)}$ Range of Concentrations ${ }^{(2,3)}, \times 10^{-6} \mu \mathrm{Ci} / \mathrm{gm}$}

\begin{tabular}{|c|c|c|c|c|}
\hline Vegetation Analyses & Bull Run/Thompson Run $^{(4)}$ & Buono Spring $^{(5)}$ & Northeast Area $^{(5)}$ & Control Stream $^{(5)}$ \\
\hline Strontium-89 & $\leq 0.048$ & $\leq 0.049$ & $\leq 0.10$ & $\leq 0.15$ \\
\hline Strontium-90 & $\leq 0.010$ to $0.15 \pm 0.043$ & $0.051 \pm 0.037$ & $0.077 \pm 0.076$ & $\leq 0.076$ \\
\hline Cesium-137 & $\leq 0.017$ & $\leq 0.026$ & $\leq 0.025$ & $\leq 0.029$ \\
\hline Cesium-134 & $\leq 0.021$ & $\leq 0.028$ & $\leq 0.027$ & $\leq 0.029$ \\
\hline Cobalt-60 & $\leq 0.036$ & $\leq 0.031$ & $\leq 0.031$ & $\leq 0.034$ \\
\hline
\end{tabular}

(1) These locations are adjacent to the routine sample points, but they are situated outside of the stream beds and the flood plains of the stream beds.

(2) Uncertainties are based on counting statistics at the $95 \%$ confidence level.

(3) $\leq$ signifies at or below the minimum detection level (MDL).

(4) Ranges are for 7 samples. Single MDL values indicate the maximum MDL result for the 7 stream samples.

(5) Single samples of vegetation were collected for these locations. 
Very low levels of Strontium-90 were detected above minimum detection levels in stream vegetation and vegetation samples along the Bull Run and Northeast Area Streams and Buono Spring. Bull Run stream vegetation results ranged from $<0.016 \times 10^{-6}$ to $0.15 \times 10^{-6} \mu \mathrm{Ci} / \mathrm{g}$. Small historical deposits of radioactivity from Site operations which ceased more than 25 years ago could be responsible for the presence of this radioactivity. A Strontium-90 result of $0.059 \times 10^{-6} \mu \mathrm{Ci} / \mathrm{g}$ was obtained in stream vegetation in the Northeast Area Stream. Strontium-90 was also detected above minimum detection levels in vegetation along the Northeast Area stream and Buono Spring. The maximum concentration was $0.077 \times 10^{-6}$ $\mu \mathrm{Ci} / \mathrm{g}$. Based on past operations, historical radioactivity releases were not conducted in these areas and the very low levels are most likely due to atmospheric fallout. However, the levels of radioactivity are so low that a person could consume several hundred pounds of this vegetation each year with the highest measured concentration of Strontium-90 and never exceed the NRC limits for individuals in unrestricted areas. Actually, this vegetation is not of the type used as a human food source.

From the above data, it was concluded that the stream sediment and vegetation analyses demonstrated that there was no evidence of any addition of radioactivity in the streambeds of the site's effluent streams. The results discussed in Section $A$ also show that the liquid radioactive effluents from the Site were being adequately controlled during 1993 such that no accumulation of radioactivity could have occurred in the site's stream sediments.

Non-Radiological: The soil investigation program consisted of a site-wide soil gas survey program and an extensive soil sampling program. The primary objective of the program was to determine the presence of potential constituents in known and suspect areas and to determine the boundaries of areas containing residual chemical constituents. The investigation confirmed previous environmental study conclusions that the primary chemical constituents in the soil are the volatile organic compounds PCE,
TCE, DCE and PCBs. In addition, the investigation determined that coal tar residues, commonly referred to as BNAs or polyaromatic hydrocarbons, were present in certain areas. The investigation determined that the soil does not contain any noteworthy amounts of heavy metals, pesticides or asbestos.

The majority of the chemical constituents are located in two inactive landfills: the IWS and BL. A third source area is the soil/fill around the site's underground storm sewer system. The VOCs in these areas have leached into the upper waterbearing zones directly under the site. PCBs and coal tar residues have not migrated to ground water in detectable amounts.

The chemical constituents in the soil are not found off-site except at one location. Some very low levels of benzo(a)pyrene were found on Valley Welding Supply Company, but this compound is ubiquitous to the region and its concentration was consistent with anthropogenic levels. Low levels of PCBs were also found to have migrated from the IWS onto Valley Welding supply company property, but the maximum concentration found was below the EPA's spill cleanup limit of $10 \mathrm{mg} / \mathrm{kg}$.

The magnitude of the chemical contamination is not large. The concentration of PCE, which is by far the most predominant of the solvents, is generally found at less than 1 part per million (ppm). The majority of the PCB concentrations are less than the spill cleanup criteria established by the EPA; only a few concentrations exceed $50 \mathrm{ppm}$ and none exceed $500 \mathrm{ppm}$. The concentrations of coal tar residues are typical of anthropogenic background levels in this area. These residues are associated with construction debris (roofing tars, etc.) ash and cinder residues and not from the disposal of any chemicals at the site.

The results of analyses of sediment samples collected from on-site and off-site streams and the inactive HTTF drainage channel confirm data obtained through historical sampling and analysis with the 
exception of the detection of the pesticide chlordane, which was previously not detected in any sediment samples.

VOCs associated with site operations were not detected in sediment samples collected from Thompson Run Stream, the Northeast Stream, or the inactive HTTF drainage channel. Sediment samples collected from Bull Run Stream and the Buono Spring discharge flow path contained VOCs. PCE was the only VOC detected in Bull Run Stream sediment. The primary source of PCE in the sediment today is the continuous discharge of water from springs (Buono Spring, RQ-20 Spring, RH Spring) and seeps that contain low levels of PCE. Because the PCE being discharged to Bull Run Stream remains relatively constant (continuous spring flow), PCE concentrations in sediment are likely to remain constant, as supported by historical data. Based on data obtained, the discharge of low levels of PCE to Bull Run Stream occurs primarily between Buono Spring and the confluence of Bull Run Stream and the Northeast Stream. The results of sediment sampling and analyses at on-site locations downstream of the Bull Run Stream/Northeast Stream confluence and off-site locations indicate that PCE in Bull Run Stream sediment is not migrating off-site to a measurable degree.

The presence of PCBs in on-site stream sediment and the inactive HTTF drainage channel is likely associated with historical disposal of wastes containing small quantities of PCBs to the storm sewer system and subsequent discharge to the various streams and the drainage channel. The PCB isomers Aroclor 1248, Aroclor 1254, and Aroclor 1260 were each detected.

BNAs detected in on-site stream and spring sediments are comparable to those present in local stream sediments unaffected by site discharges and are not associated with any site-specific operations, past or present.
Summaries of the results of the RFI samples and the results discussed above were reported to the EPA and PA-DER in Bimonthly Progress Reports required by the Consent Order. The analytical results and an interpretation of their significance were contained in the Draft RFI Report submitted to the regulatory agencies in December 1993.

\section{E. RADIATION MONITORING}

The purpose of the environmental radiation monitoring program is to measure and verify that Site operations do not alter the natural radiation background around the Site.

\section{Radiation Sources}

The source of radiation at the Site includes small specimens of irradiated and unirradiated fuel materials which are handled, processed, and stored at the Site. There are no nuclear reactors at the Site.

\section{Radiation Monitoring}

Environmental radiation levels were monitored in the vicinity of the Site with a network of lithium fluoride thermoluminescent dosimeters (TLDs). The approximate locations of the Site TLD monitors are shown on Figure 5. Control TLD monitors were posted at locations remote from the Site to measure the natural background radiation levels typical for western Pennsylvania. The control TLDs were located in nearby communities (Pleasant Hills, Reserve Township, Greensburg, Mt. Pleasant, Elizabeth, and Port Vue, PA). All TLD monitors were posted for quarterly exposure periods.

In addition to the TLD network which was the primary monitoring method, a radiation survey was conducted around the site perimeter. 


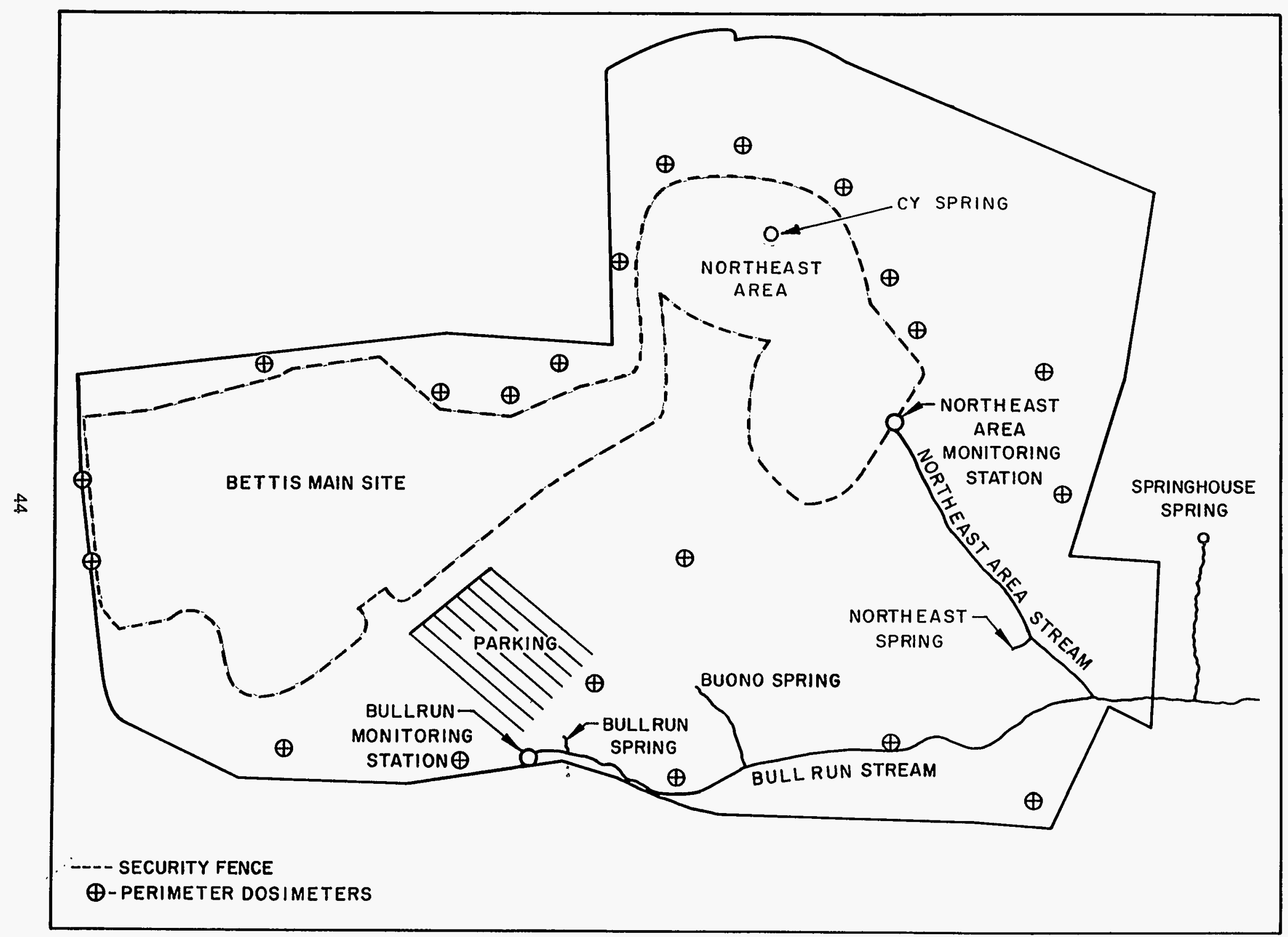

FIGURE 5 ENVIRONMENTAL DOSIMETER LOCATIONS 


\section{Radiation Analyses}

The environmental TLDs were calibrated by a 25 mrem exposure to a Cesium-137 standard source. Only TLDs which exhibited a response within $\pm 10 \%$ of the mean response were selected for environmental radiation monitoring. The TLD radiation exposures were measured quarterly utilizing an automated TLD readout system which was calibrated prior to the processing of the TLDs. The environmental TLDs were annealed prior to posting and were read out following collection. TLD results were corrected to assure that the environmental TLDs reflected only the exposure received during the time they were posted in the field.

The perimeter radiation survey was conducted using a highly sensitive radiation instrument (PRM-7). This instrument was calibrated with Cesium-137 within six months prior to use and source checked for proper operation immediately prior to use.

\section{Radiation Monitoring Results and Conclusions}

The TLD results in Table 13 summarize the radiation levels measured during each quarter of 1993 at the Site boundary and at the off-site locations. These results agree, within measurement uncertainties, with the radiation levels measured at locations remote from the Site. The annual average radiation exposure for the TLDs at the site perimeter was $65 \mathrm{mrem}$. The annual average radiation exposure at the off-site locations was $65 \mathrm{mrem}$.

A statistical t-ratio test (Student-t) was used to examine the differences in the mean values for the site perimeter and the off-site TLD radiation exposures. Based on the results, it was concluded that the TLD sample data for the site perimeter and for the off-site locations belong to the same population. Thus the exposure received by an individual located at the site perimeter is not different from that received from background radiation in the surrounding area.

The radiation dose rates measured during a survey along the Site boundary averaged approximately $0.007 \mathrm{mrem} / \mathrm{hr}$ which, integrated over the TLD

exposure period in 1993, predicted an annual exposure of $64 \mathrm{mrem}$. The 1993 radiation monitoring results were consistent with the range of natural radiation levels of 82 to $104 \mathrm{mrem} /$ year observed in a U.S. Public Health Service survey of the northwest and southwest areas of Pennsylvania (Reference (9)).

Also, the radiation monitoring results were consistent with the range of natural radiation levels of 79 to $105 \mathrm{mrem} /$ year determined by an aerial radiation survey, Reference (10), that encompassed a 100 square-mile area around the Site. Therefore, it was concluded that the radiation exposure to the general public at the Site perimeter was not above the exposure received from natural background radiation.

\section{Bull Run Stream/West Mifflin Park Survey}

During April 1993, Bettis personnel and a representative of the PA-DER performed an environmental radiation survey of a portion of the Bull Run Stream basin in the West Mifflin Community Park. This portion of the basin was selected because it represents the only segment of Bull Run in the West Mifflin Park area that contains low levels of Bettis-generated radioactivity above natural background levels in the soil. Radiation measurements were taken and recorded on a $10^{\prime}$ by $10^{\prime}$ grid system at approximately three feet above the ground surface. The area within each 100 square foot grid section was scanned. Radiation measurements were taken by Bettis personnel at all locations using the 
TABLE 13

ENVIRONMENTAL RADIATION MEASUREMENTS IN THE VICINITY OF THE BETTIS LABORATORY CY $1993^{(1)}$

\begin{tabular}{|c|c|c|c|c|c|c|c|c|c|}
\hline $\begin{array}{l}\text { Quarterly } \\
\text { TLD } \\
\text { Exposure } \\
\text { Period }\end{array}$ & $\begin{array}{l}\text { Number } \\
\text { of } \\
\text { Exposure } \\
\text { Days }\end{array}$ & $\begin{array}{c}\text { Number } \\
\text { of On-site } \\
\text { Measurements }\end{array}$ & $\begin{array}{l}\text { Mean } \\
\text { (mrem) }\end{array}$ & $\begin{array}{c}\text { Max. } \\
\text { (mrem) }\end{array}$ & $\begin{array}{l}\text { Min. } \\
\text { (mrem) }\end{array}$ & $\begin{array}{c}\text { Number } \\
\text { of Off-site } \\
\text { Measurements }\end{array}$ & $\begin{array}{l}\text { Mean } \\
\text { (mrem) }\end{array}$ & $\begin{array}{c}\text { Max. } \\
\text { (mrem) }\end{array}$ & $\begin{array}{c}\text { Min. } \\
\text { (mrem) }\end{array}$ \\
\hline First & 91 & 21 & $18.0 \pm 1.2$ & 19.1 & 16.7 & 6 & $19.5 \pm 5.1$ & 24.7 & 14.5 \\
\hline Second & 91 & 21 & $15.7 \pm 1.2$ & 16.9 & 14.5 & 6 & $15.5 \pm 5.7$ & 21.3 & 9.9 \\
\hline Third & 91 & 20 & $15.6 \pm 1.3$ & 16.9 & 14.3 & 6 & $15.4 \pm 7.3$ & 22.7 & 8.1 \\
\hline Fourth & 91 & 20 & $16.1 \pm 1.2$ & 17.3 & 14.9 & 6 & $14.4 \pm 4.6$ & 19.0 & 9.8 \\
\hline
\end{tabular}

(1) The uncertainties are within $95 \%$ confidence level. 
very portable Eberline PRM-7

environmental survey meter. Select

measurements were repeated with the highly accurate but cumbersome Reuter-

Stokes RS-111 environmental survey meter to confirm the normal overresponse of the PRM-7. The radiation levels, as measured by the RS-111, varied from background of about 10 microroentgen per hour (uR/hr) to a maximum of $27 \mathrm{uR} / \mathrm{hr}$. These slightly enhanced radiation levels are due to the presence of low levels of radioactivity, primarily Cesium-137, from early Site operations. These levels and locations are consistent with previously measured and reported values and indicate that there is no migration or buildup of radioactivity into of from the area.

Soil samples were also collected from the surface down to rock at ten locations to determine the radioactivity profile in the soil. The results confirm that the primary radionuclide present is Cesium-137. Cesium-137 radioactivity ranged from background to $1.2 \times 10^{-4} \mu \mathrm{Ci} /$ gram. The data also show low levels of natural uranium in the soil. These data are consistent with previous data reported. The data demonstrate that the majority of the radioactivity is in the top one foot or less of the soil. This profile is consistent with deposition from flooding of the area and the affinity of Cs-137 for soil particles.

The survey and soil sample results confirm that very low levels of radioactivity from early Site operations are present in a small area within the Bull Run basin in West Mifflin Park. The survey results confirm that the residual radioactivity is not migrating from or building up in the area. The areas where the residual radioactivity is located are undeveloped and unoccupied. Therefore, the most probable radiation dose received by any person from these residues is zero. However, even in the unlikely event that a person would spend one hour each day in the area where the radiation level is the highest, the yearly dose received would be far below that allowed for members of the general public by the NRC regulations specified in Reference (5).

\section{F. CONTROL OF CHEMICAL AND HAZARDOUS WASTES}

\section{Origin}

The necessary use of chemicals at the Site during 1993 resulted in the generation of relatively small volumes of chemical and hazardous wastes. These wastes included acid solutions, polychlorinated biphenyls, photographic solutions, oil solutions containing metals and organic solvents and other organic solvent contaminated solids.

\section{Control Program}

All hazardous wastes were managed in accordance with RCRA and the environmental regulations of the Commonwealth of Pennsylvania. Nonhazardous chemical wastes were managed in accordance with the Site's NPDES permit and applicable federal and state regulations. The control programs minimized the quantity of routine waste material generated, assured safe use and storage of the materials on-site, and provided for proper disposal of the wastes by vendors who operated under permits issued by federal and state agencies.

A principal component of the overall program was the control of the acquisition of chemicals for use at the Site. Purchase orders for chemicals were reviewed to assure that potentially hazardous materials were necessary, that the amounts ordered were not excessive, and that procedures for use and disposal were in place before the materials were ordered. The Site also used a chemical exchange program where groups within the Site exchange chemicals rather than purchase new ones.

Specific training was provided to personnel who handled hazardous materials to assure that they were knowledgeable of safe handling techniques and emergency response procedures. After chemicals were used and no longer needed, they were accumulated in designated staging and storage areas where they were segregated and packaged for shipment. Storage and accumulation areas were 
inspected periodically to verify that hazardous materials were properly stored and controlled in accordance with approved procedures. Waste was stored only as necessary to accumulate sufficient volume for economical shipment to a waste disposal vendor.

\section{Treatment and Disposal}

No chemical or hazardous materials were disposed of at the Bettis-Pittburgh Site. Approximately 344,305 pounds of chemical and hazardous waste were transported by vendors to treatment/storage/disposal (TSD) facilities for final disposition. This total includes about 309,401 pounds of remediation wastes. The transportation vendors and the TSD facilities operate under approvals or permits granted by the cognizant state and federal regulatory agencies. Written documentation was received from the TSD facilities verifying that the waste was received and handled in accordance with requirements. The Site chose vendors with treatment and disposal methods that would reduce long term concerns and threats to the environment.

Also during 1993, the PA-DER conducted an on-site inspection of the RCRA program at the Site. The Site was found to be in compliance. No violations or items of noncompliance were found with current operations.

\section{G. CONTROL OF RADIOACTIVE WASTE MATERIALS}

\section{Origin}

Operation of the Site during 1993 resulted in the generation of various types of lowlevel radioactive waste material. This material included liquids, filters, metal scrap, rags, resin, paper, soil, and plastic.

\section{Control Program}

The volume of waste containing radioactivity was minimized through the use of detailed work procedures and worker training to limit the amount of material that contacted radioactivity during work on radioactive systems and components; waste compaction was also used.

Detailed procedures were used during generation, handling, packaging and transportation of radioactive waste material. All radioactive wastes shipped off-site were packaged in accordance with applicable DOE disposal site criteria and the DOT regulations in Reference (11). In addition, all radioactive liquids were solidified prior to each shipment. Internal reviews were made prior to the shipment to ensure that the material was properly identified, surveyed, and packaged in accordance with federal and burial site requirements.

\section{Disposal}

Shipments of solid radioactive waste were made to an off-site DOE burial ground. During 1993, approximately 575 cubic meters of radioactive waste containing about 2.66 Curies of radioactivity were shipped from the Bettis site for burial. This is less than $1 \%$ of the volume of low-level radioactive waste typically disposed of annually by all DOE-owned facilities.

\section{H. ENVIRONMENTAL AND EFFLUENT MONITORING QUALITY ASSURANCE}

Radiological: The Site maintained an internal quality control program as well as participated in an interlaboratory quality assurance program in cooperation with the DOE (Environmental Measurements Laboratory, EML) and the EPA Nuclear Radiation Assessment Division. These programs were designed to test and demonstrate consistency and continued precision and accuracy of the Site's radioanalytical techniques and results. The requirements for internal quality control followed the guidelines and practices recommended by the NRC in Reference (12) and the EPA in References (6) and (13).

The EPA and DOE transmitted samples of water, air filters, vegetation, and soil for radiological analyses. Results were furnished to both agencies and are 
published periodically. Appendices $A$ and $B$ summarize the results from the radiological quality assurance cross-check programs. During 1993, the Site demonstrated satisfactory performance in obtaining analytical results which met with the acceptance criteria of both the DOE and the EPA Quality Assurance Programs.

Non-Radiological: To demonstrate the precision and accuracy of the nonradiological analyses conducted for samples of influent city water and effluent water from the Site, quality control samples were submitted to the off-site contract laboratories. These samples consisted of reference standards obtained from the EPA or from a commercial source. The results of the quality control samples are contained in Appendix C. During 1993, the off-site contractor laboratories demonstrated satisfactory performance in the quality control program.

All sampling and analysis done under the RFI was performed in accordance with the EPA approved quality assurance programs contained in the RFI workplans.

In addition, the off-site contractor laboratories were required to submit backup data for all analyses. These data were validated by chemists in the Bettis Analytical Chemistry group. This review entailed a check of calculations, standards, graphs and spike results. Trends that might indicate a problem in the contractor laboratory's programs were also evaluated. Problems noted in the review were resolved with the laboratory before final acceptance of the data.

\section{ASSESSMENT OF RISK TO CHEMICAL RESIDUES}

A risk assessment (RA) was prepared as part of the Site's RFI. This assessment was prepared using the Superfund related methodology outlined in Reference (14). The detailed assessment, presented in the Draft RFI Report, is summarized below.

The objective of the assessment was to determine the reasonable maximum exposure (RME) of on-site and off-site populations to environmental contamination at the Site. The media containing chemical residues are soil, ground water, surface water (springs and streams), and sediment. Residues whose concentrations exceeded the EPA Region Ill's risk-based screening levels were selected as potential contaminants of concern (PCOCs). The residues evaluated were largely VOCs, PCBs, and PAHs.

Risks were evaluated for realistic industrial land-use scenarios, now and in the future. EPA exposure default parameters were used for off-site commercial/industrial workers. Site-specific exposure parameters were used for pathways where standard EPA values were not available or were not appropriate. All exposure pathways judged to be complete now and in the future were quantified. Ground water exposure was not quantified because the Site and off-site populations receive municipal water and this is unlikely to change for the foreseeable future for the following reasons:

- The municipal water supply is convenient, reliable, and safe;

- The ground water is inherently of poor quality due to high concentrations of naturally occurring metals;

- Some downgradient ground water is contaminated with domestic sewage from residents discharging sewage directly into the ground and from malfunctioning sewage lift stations;

- Water yields are low for the five upper water-bearing zones beneath the Site, and;

- The expense is high to install and operate production wells.

The RA quantified carcinogenic risk and noncarcinogenic hazard for four potentially exposed populations:

- On-site construction workers exposed to chemical residues in soil; 
- Off-site commercial/industrial workers exposed to chemical residues in soil;

- Trespassing children exposed to chemical residues in water and sediment in springs and streams; and

- Off-site children exposed to chemical residues in water in a spring and sediment in a stream.

Based on EPA criteria, the calculated carcinogenic risk and noncarcinogenic hazard values were compared with the values of $1.0 \times 10^{-6}$ and 1.0, respectively, which represent acceptable risk levels.

For on-site construction workers engaged in excavation activities, carcinogenic risks were quantified for all on-site locations where PCOCs were present. The noncarcinogenic hazard could be calculated only for one site and the value was several orders of magnitude below the comparison criterion of 1.0. The estimated carcinogenic risks did not exceed the comparison criterion of $1.0 \times 10^{-6}$ at any location, with the highest being $5.4 \times 10^{-7}$ for soil in the IWS.

For off-site workers at the Valley Welding Supply Company (MWSC), the estimated carcinogenic risk from exposure to PCBs and benzo(a)pyrene in surface soil is $1.7 \mathrm{X}$ $10^{-5}$. This risk estimate is judged to be highly conservative due to the assumptions used in calculating intake (exposure of 250 days/year for 25 years) and because the chemical residues in the soil are on a part of the Valley Welding property remote from the main work area.

Exposure to surface water and sediment in the on-site and off-site streams and springs was quantified for children, the only group that might have more than occasional contact with these media. The highest estimated risk was $1.0 \times 10^{-7}$ for exposure to Thompson Run Stream sediment, which is below the comparison criterion of $1.0 \times 10^{-6}$. Noncarcinogenic hazards were several orders of magnitude below the comparison criterion of 1.0 .

In summary, chemical residues in the environment at the Site do not pose significant health risks to potentially exposed populations using reasonable maximum exposure assumptions. The only study area with a carcinogenic risk estimate exceeding the comparison criterion is Valley Welding Supply Company soil, with a maximum carcinogenic risk of $1.7 \times 10^{-5}$. However, exposure (dermal contact, ingestion, and inhalation) for 250 days/year for 25 years is required to achieve this risk. This risk is believed to be highly conservative given that the contaminated portions of the company's property are in infrequently accessed or undeveloped locations. In reality, the risk at Valley Welding Supply Company is probable less than $1.0 \times 10^{-6}$. Non-carcinogenic risks were all significantly less than the comparison criteria of 1.0 .

\section{J. ASSESSMENT OF RADIATION DOSE- TO-MAN}

Effluent monitoring results at the Site during 1993 demonstrated that radioactivity releases were negligible and well below the federal radioactivity concentration guides. Radiation exposure to the general public from airborne releases was too low to measure and could only be determined with calculational models using the effluent radioactivity data. Therefore, a conservative assessment of the radiation dose-to-man was performed by analyzing the exposure pathways whereby radioactivity might be transmitted from the Site to the general public. The following potential exposure pathways were considered in this assessment:

1. immersion in the atmosphere containing the released radionuclides and their daughters,

2. ingestion of food directly contaminated by the release or produced in regions subjected to prior contamination,

3. an inhalation of gaseous and suspended radioactivity,

4. exposure to ground deposits and deposits in bodies of water,

5. ingestion of radioactivity in the drinking water supply, and

6. direct radiation from Site operations. 
Specific radionuclide composition of the airborne and liquid releases was factored into the assessment. The dose for each exposure pathway was explicitly calculated for each radionuclide and applicable daughters. The air pathway calculations used wind direction data and meteorological parameters that were measured by the Bettis-Pittsburgh Site meteorological monitoring system in 1993. The Site meteorological monitoring system utilizes a Handar tower which measures wind speed, gusts, wind direction, temperature, relative humidity, and inches of rain. The measurements are integrated over 15-minute intervals. The tower is part of the Atmospheric Release Advisory Capability (ARAC) service developed by Lawrence Livermore National Laboratory to model the atmospheric release of radioactive materials. The population distribution in the vicinity of the Site was based on 1980 census data. The atmospheric dispersion of the Site's radioactive airborne releases and resulting dose were calculated using an EPA approved computer program described in Reference (15). The dose due to liquid effluents was determined by modeling the diluted effluents to the nearest drinking water supply. Specific volumes and flow rates typical of the effluent streams and the Monongahela River were used. In addition, References (16) through (19) were used in conjunction with the liquid effluent dilution to calculate the radiation doses-to-man. The radiation dose assessment of airborne and liquid radioactivity releases attributed to Site operations during 1993 are presented in Table 14. Radiation doses were calculated for the whole body and most limiting organ of individuals at locations of maximum exposure on the site boundary and for the total population within 50 miles of the Site.

The results in Table 14 show that the maximum whole body radiation exposure which any member of the public could hypothetically receive due to past and present operations ranged from 0.3 to 2.6 mrem. Nearly all of this very low potential dose would be from gaseous radioactivity and from exposure to the Bull Run soil and sediments that contain residual radioactivity from operations over 25 years ago. Based on a conservative estimate that an individual would spend as much as one hour per day, every day of the year, walking along the Bull Run stream bank in the areas with radiation levels above background, the annual hypothetical dose received would be approximately 2.3 mrem. This is less than the amount of additional radiation exposure an individual would receive from a cross country airplane flight (Reference 20). The maximum potential radiation dose is well below the most restrictive dose limits of the Nuclear Regulatory Commission as provided in Reference (5) or of the DOE and is less than $1 \%$ of the radiation exposure a person receives from naturally occurring radiation in the environment $(300$ mrem per year (Reference 19)). The dose resulting from the low levels of radioactivity in the laboratory airborne effluent is significantly less than the limits of the EPA in Reference (6).

In conclusion, the maximum radiation exposure to any member of the public as a result of operations at the Bettis Site during 1993 was substantially below the radiation exposure limits established by the EPA, DOE, and NRC. Moreover, the accumulated radiation exposure received during 1992 by the total population of $3,200,000$ within 50 miles of the site was conservatively estimated to be approximately 3.0 man-rem which is negligible compared to the approximately 960,000 man-rem dose received from natural background radiation. Therefore, the radioactivity released from the Site, as a result of past and present operations, has not resulted in any significant radiation exposure to the general public.

\section{K. ENVIRONMENTAL PERMITS}

The Bettis-Pittsburgh Site has obtained or applied for the environmental permits required by the applicable regulations. Appendix $D$ provides a listing of the environmental permits for the Site. The Site has operating permits, as required by the ACHD, for certain fuel-burning equipment. The Site also has a NPDES permit governing the discharge of plant waste waters to local streams. A RCRA Part $B$ permit application has been submitted for a facility for the storage of on-site-generated hazardous waste pending shipment off-site. The facility is currently being operated in compliance with the RCRA requirements for interim status pending issuance of the Part $B$ permit. 
TABLE 14

\section{SUMMARY OF CALCULATED RADIATION DOSE-TO-MAN \\ FROM SITE OPERATIONS, CY 1993}

A. Maximum Hypothetical Radiation Exposure to an Off-Site Individual at the Bettis Site Perimeter

\section{Liquid Pathways}

2. Airborne Pathways
a. Particulate Radioactivity ${ }^{(3)}$ Release
b. Gaseous Radioactivity Release ${ }^{(4)}$
c. EPA Limit
0.0006
0.267
1.95 (endosteal)

$\begin{array}{ll}\text { Effective } & \text { Maximum Dose } \\ \text { Whole Body } & \text { Limiting Organ }\end{array}$

Negligible $^{(2)}$

Negligible

\section{Direct Exposure Pathways}
a. Direct Radiation from Bettis Operations
Negligible
Negligible
b. Exposure to Bull Run Stream Sediments
$0-2.3$
$0-2.3$ (whole body)

Maximum Whole Body Dose

to Individual

$\sim 0.3-2.6$

DOE Limit

100
B. 50-Mile Population Radiation Exposure

\section{Estimated Population Dose Equivalent ${ }^{(3)}$, (man-rem) \\ Whole Body \\ Maximum Dose \\ Limiting Organ}

1. Liquid Pathways

Negligible

Negligible

2. Airborne Pathways

2.99

21.9 (endosteal)

3. Direct Exposure Pathways

$0-0.01$

$0-0.01$ (whole body)

Maximum Whole Body

$<3.0$

Population Dose 


\section{SUMMARY OF CALCULATED RADIATION DOSE-TO-MAN FROM SITE OPERATIONS, CY 1993}

(1) The dose estimated for the liquid and airborne pathways is the committed "50-year" effective dose equivalent for the radiation exposure potentially received by an individual over a 50-year period following the ingestion or inhalation of the radioactivity released in this calendar year.

(2) The Site did not discharge any radioactivity due to current operations into the liquid effluent streams.

(3) The principal contributors to the calculated dose from particulate radioactivity releases were conservatively assumed to be Cobalt-60 and Thorium-232.

(4) The contributors to the gaseous radioactivity releases were Radon-220 and its daughters, Antimony-125, and lodine-131. The principal contributor was Radon-220 and its daughters. Since the 40 CFR 61 - Subpart $H$ reporting requirements for the effective dose equivalent due to airborne radionuclides specifically excludes radon, the value given in that report of $0.001 \mathrm{mrem}$ does not include the $0.266 \mathrm{mrem}$ due to radon provided in this report. 


\section{REFERENCES}

(1) Draft RFI Report for the Bettis Site, West Mifflin, Pennsylvania, December, 1993.

(2) Bettis Environmental Monitoring Procedures Manual, WAPD-RC/E(HE)-407.

(3) Bettis Environmental Controls Manual, EC-1.

(4) Title 40, Code of Federal Regulations, Part 136, Guidelines Establishing Test Procedures for the Analysis of Pollutants.

(5) Title 10, Code of Federal Regulations, Part 20, Standards for Protection Against Radiation.

(6) Test Methods for Evaluating Solid Waste Physical/Chemical Methods, U.S. EPA, SW-846.

(7) Title 40, Code of Federal Regulations, Part 61, National Emission Standards for Hazardous Air Pollutants; Subpart H - National Emission Standard for Radionuclide Emissions from Department of Energy (DOE) Facilities.

(8) Allegheny County Health Department Rules and Regulations, Article XX, Air Pollution Control.

(9) "Summary of Natural Environmental Gamma Radiation Using a Calibrated Portable Scintillation Counter", Radiological Health Data and Reports, Volume 9, Number 11, pp. 620-695, November, 1968.

(10) "An Aerial Radiological Survey of West Mifflin, Pennsylvania, and Surrounding Areas". EG\&G/EM Survey Report, DOE/NR-8319, dated March, 1984.

(11) Title 49, Code of Federal Regulations, Part 171 through 179, Hazardous Material Regulations.

(12) NRC Regulatory Guide 4.15, dated February, 1979.

(13) "Handbook for Analytical Quality Control in Radioanalytical Laboratories," EPA-600/17-77-008, dated August, 1977.

(14) Risk Assessment Guidance for Superfund (RAGS) Volume I (Part A), Human Health Evaluation Manual, USEPA, 1989b.

(15) The Clean Air Act Assessment Package - 1988 (CAP-88) - A Dose and Risk Assessment Methodology for Radionuclide Emissions to Air, CAP88-PC, Version 1.0, March, 1992.

(16) DOE/EH-0071, "Internal Dose Conversion Factors for Calculation of Dose to the Public", U.S. Department of Energy, July 1988.

(17) DOE/EH-0070, "External Dose-Rate Conversion Factors for Calculation of Dose to the Public", U.S. Department of Energy, July 1988. 


\section{REFERENCES (Continued)}

(18) ICRP Publication 30, "Limits for Intakes of Radionuclides by Workers", International Commission on Radiological Protection, Pergamon Press, 1978.

(19) ICRP Publication 23, "Report of the Task Group on Reference Man", International Commission on Radiological Protection, Pergamon Press, 1974.

(20) NCRP Report No. 94, "Exposure of the Population in the United States and Canada from Natural Background Radiation", December, 1987. 
Admiral B. DeMars, Deputy Assistant Secretary for

Naval Reactors

Department of Energy

Washington, D.C. 20585

Mr. H. A. Cardinali, Manager

Pittsburgh Naval Reactors Office, DOE

Post Office Box 109

West Mifflin, Pennsylvania 15122

Office of Environmental Guidance \& Compliance, EH-23

Department of Energy

Washington, D.C. 20585

Mr. A. A. Davis, Secretary

Department of Environmental Resources

Commonwealth of Pennsylvania

9th Floor Fulton Building

Post Office Box 2063

Harrisburg, Pennsylvania 17120

Mr. Terry A. Pallas, Chief

Operations Section

Bureau of Water Quality Management

Pennsylvania Department of Environmental Resources

Commonwealth of Pennsylvania

400 Waterfront Drive

Pittsburgh, Pennsylvania 15222

Mr. James Yusko

Bureau of Radiological Health

Pennsylvania Department of Environmental Resources

Commonwealth of Pennsylvania

400 Waterfront Drive

Pittsburgh, Pennsylvania 15222

Mr. Christopher B. Pilla, Chief

Corrective Action RCRA Enforcement Section

Environmental Protection Agency, Region III

841 Chestnut Building

Philadelphia, Pennsylvania 19107

Mr. Richard V. Pepino, Chief

Environmental Assessment Branch

Environmental Protection Agency, Region III

841 Chestnut Building

Philadelphia, Pennsylvania 19107 
Headquarters Library

Washington, D.C. 20585

U.S. Department of Energy

Technical Information Center

Post Office Box 62

Oak Ridge, Tennessee 37831

Science and Technology Department

Carnegie Library of Pittsburgh

4400 Forbes Avenue

Pittsburgh, Pennsylvania 15213

Mr. Ronald J. Chleboski, Deputy Director

Division of Air Quality

Bureau of Environmental Quality

Allegheny County Health Department

301 Thirty-ninth Street

Pittsburgh, PA 15201

Mr. Joseph W. Chnupa

Assistant Regional Director

Southwest Region

Department of Environmental Resources

Commonwealth of Pennsylvania

400 Waterfront Drive

Pittsburgh, PA 15222

The Honorable Arlen Specter

U. S. Senate

Washington, D.C. 20510

The Honorable Rick Santorum

U. S. House of Representatives

Washington, D. C. 20515

The Honorable Albert V. Belan

Capitol Building

Harrisburg, PA 17120

The Honorable Richard D. Olasz

Capital Building

Harrisburg, PA 17120

Howard Bednar

Borough Manager

West Mifflin Borough

4733 Greensprings Avenue

West Mifflin, PA 15122 
Leon L. Kuchinski, Division Chief

Division of Hazardous Waste Management

Bureau of Solid Waste Management

Department of Environmental Resources

Commonwealth of Pennsylvania

P. O. Box 8471

Harrisburg, PA 17105

Maria Parisi-Vickers, Associate Director

Office of RCRA Programs

U. S. Environmental Protection Agency

Region III

841 Chestnut Building

Philadelphia, PA 19107

Peter H. Kostmayer, Regional Administrator

U. S. Environmental Protection Agency

Region III

841 Chestnut Building

Philadelphia, PA 19107 


\section{USEPA Cross Check Results - CY 1993}

In addition to an internal Quality Assurance program, the Bettis-Pittsburgh facility participates in USEPA and DOE-sponsored external quality control sample analysis programs. On a periodic basis, samples are provided to Bettis and analyzed for various radiological attributes to verify the continuing analytical capabilities of Bettis. Appendix A lists the results of the analyses reported for USEPA programs, and Appendix $B$ lists the results of the analysis reported for the DOE Program.

\begin{tabular}{|c|c|c|c|c|c|c|}
\hline DATE & ATTRIBUTE & $\begin{array}{l}\text { REPORTED } \\
\text { VALUE }^{(1)}\end{array}$ & $\begin{array}{l}\text { KNOWN } \\
\text { VALUE }\end{array}$ & $\underline{\text { Units }}{ }^{(2)}$ & $\underline{N D(X o)^{(2)}}$ & Note \\
\hline Oct92-Water & $\begin{array}{c}U \\
\text { Sr89 } \\
\text { Sr90 } \\
\text { Co60 } \\
\text { Cs134 } \\
\text { Cs137 }\end{array}$ & \begin{tabular}{|c|}
11.7 \\
7.3 \\
10.8 \\
14.3 \\
5.8 \\
8.7
\end{tabular} & $\begin{array}{c}10.2 \pm 3 \\
8.0 \pm 5 \\
10.0 \pm 5 \\
15 \pm 5 \\
5.0 \pm 5 \\
8.0 \pm 5\end{array}$ & pCi/liter & $\begin{array}{l}0.67 \\
1.39 \\
-0.23 \\
-0.23 \\
-0.46 \\
0.58\end{array}$ & 4 \\
\hline Jan93-Water & $\begin{array}{c}\text { Gross Alpha } \\
\text { Gross Beta }\end{array}$ & $\begin{array}{c}8.0 \\
44.3\end{array}$ & $\begin{array}{l}34 \pm 9 \\
44 \pm 5\end{array}$ & pCi/liter & $\begin{array}{l}-5.0 \\
0.12\end{array}$ & 5 \\
\hline Jan93-Water & $\begin{array}{l}\text { Sr89 } \\
\text { Sr90 }\end{array}$ & $\begin{array}{c}14.3 \\
9.0\end{array}$ & $\begin{array}{c}15 \pm 5 \\
10.0 \pm 5\end{array}$ & pCi/liter & $\begin{array}{l}-0.23 \\
0.35\end{array}$ & \\
\hline Feb93-Water & $u$ & 7.9 & $7.6 \pm 3$ & $\mathrm{pCi} /$ liter & 0.17 & \\
\hline April93-Water & $\begin{array}{c}U \\
\text { Sr89 } \\
\text { Sr90 } \\
\text { Co60 } \\
\text { Cs134 } \\
\text { Cs137 }\end{array}$ & \begin{tabular}{l|l|}
30.1 & \\
41.7 & \\
25.3 & \\
36.0 & \\
27.7 & \\
31.7 &
\end{tabular} & $\begin{array}{l}28.9 \pm 3 \\
41.0 \pm 5 \\
29.0 \pm 5 \\
39.0 \pm 5 \\
27.0 \pm 5 \\
32.0 \pm 5\end{array}$ & pCi/liter & $\begin{array}{r}0.69 \\
0.23 \\
-1.27 \\
-1.04 \\
0.23 \\
-0.12\end{array}$ & \\
\hline June93-Water & $\begin{array}{l}\text { Co60 } \\
\text { Zn65 } \\
\text { Ru106 } \\
\text { Ba133 }\end{array}$ & $\begin{array}{l}17.3 \\
98.7 \\
97.0 \\
95.7\end{array}$ & $\begin{array}{c}15.0 \pm 5 \\
103.0 \pm 10 \\
119.0 \pm 12 \\
99.0 \pm 10\end{array}$ & $\mathrm{pCi} /$ liter & $\begin{array}{l}0.81 \\
-0.75 \\
-3.18 \\
-0.58\end{array}$ & 6 \\
\hline July93-Water & $\begin{array}{c}\text { Gross Alpha } \\
\text { Gross Beta }\end{array}$ & $\begin{array}{c}13 \\
40.7\end{array}$ & $\begin{array}{c}15 \pm 5 \\
43 \pm 6.9\end{array}$ & pCi/liter & $\begin{array}{l}-0.69 \\
-0.58\end{array}$ & \\
\hline July93-Water & $\begin{array}{l}\text { Sr89 } \\
\text { Sr90 }\end{array}$ & $\begin{array}{l}34.0 \\
22.0\end{array}$ & $\begin{array}{c}34.0 \\
25.9 \pm 5\end{array}$ & pCi/liter & $\begin{array}{r}0.00 \\
-1.04\end{array}$ & \\
\hline Aug93-Water & $\mathrm{U}$ & 26.83 & $25.3 \pm 3.0$ & $\mathrm{pCi} /$ iter & 0.89 & \\
\hline Aug93-Air Filter & $\begin{array}{c}\text { Gross Alpha } \\
\text { Gross Beta } \\
\text { Sr90 } \\
\text { Cs137 }\end{array}$ & $\begin{array}{l}21.0 \\
57.0 \\
18.3 \\
13.0\end{array}$ & $\begin{array}{c}19.0 \pm 5.0 \\
47.0 \pm 5.0 \\
19.0 \pm 5.0 \\
9.0 \pm 5.0\end{array}$ & $\mathrm{pCi} /$ filter & $\begin{array}{r}0.69 \\
3.46 \\
-0.23 \\
1.27\end{array}$ & 7 \\
\hline Oct93-Water & $\begin{array}{c}\text { Gross Alpha } \\
\text { Gross Beta }\end{array}$ & $\begin{array}{l}18.7 \\
16.7\end{array}$ & $\begin{array}{l}20.0 \pm 5.0 \\
15.0 \pm 5.0\end{array}$ & pCi/liter & $\begin{array}{l}-0.46 \\
0.58\end{array}$ & \\
\hline Oct93-Water & $\begin{array}{c}U \\
\text { Sr89 } \\
\text { Sr90 } \\
\text { Co60 } \\
\text { Cs134 } \\
\text { Cs137 }\end{array}$ & $\begin{array}{c}15.73 \\
14.33 \\
11.0 \\
13 \\
10.0 \\
11.3\end{array}$ & $\begin{array}{l}15.1 \pm 3.0 \\
15.0 \pm 5.0 \\
10.0 \pm 5.0 \\
10.0 \pm 5.0 \\
12.0 \pm 5.0 \\
10.0 \pm 5.0\end{array}$ & pCi/liter & $\begin{array}{r}0.36 \\
-0.23 \\
0.35 \\
1.04 \\
-0.69 \\
0.46\end{array}$ & \\
\hline
\end{tabular}




\section{APPENDIX A \\ USEPA Cross Check Results - CY 1993}

\begin{tabular}{|c|c|c|c|c|c|}
\hline DATE & ATTRIBUTE & $\begin{array}{l}\text { REPORTED } \\
\text { VALUE }^{(1)}\end{array}$ & $\begin{array}{l}\text { KNOWN } \\
\text { VALUE }\end{array}$ & $\underline{\text { Units }}{ }^{(3)}$ & $\mathrm{ND}\left(X_{\sigma}\right)^{(2)}$ \\
\hline Nov93-Water & $\begin{array}{l}\text { Co60 } \\
\text { Zn65 } \\
\text { Ru106 } \\
\text { Cs134 } \\
\text { Cs137 } \\
\text { Ba133 }\end{array}$ & $\begin{array}{c}30.3 \\
157.7 \\
186.7 \\
53.3 \\
43.3 \\
80.7\end{array}$ & $\begin{array}{c}30.0 \pm 5.0 \\
150.0 \pm 15.0 \\
201.0 \pm 20.0 \\
59.0 \pm 5.0 \\
40.0 \pm 5.0 \\
79.0 \pm 8.0\end{array}$ & $\mathrm{pCi} /$ liter & $\begin{array}{r}0.11 \\
0.89 \\
-1.24 \\
-1.96 \\
1.15 \\
0.36\end{array}$ \\
\hline
\end{tabular}

Notes:

1. Results are the average of the analysis of triplicate aliquots.

2. Normalized deviation from the known value as described in EPA-600/7-77-088 dated August, 1977; \pm 2 are considered the warning limits and \pm 3 are considered the control limits.

3.

One picocurie $(\mathrm{pCi})=10^{-6}$ microcuries $(\mu \mathrm{Ci})$.

4. The reported values listed in this table are one half the value of those reported to the EPA; an error in dilution of the original sample as supplied by the EPA was made. This sample was received and values were reported in 1992; however, the results were not received from the EPA until after the previous Bettis-Pittsburgh report was issued.

5.

The EPA for the first time provided a gross alpha/beta sample which was spiked with Th-230 rather than Am-241, which had been their custom. Bettis-Pittsburgh instrumentation used for gross alpha analyses is calibrated using Am-241, which has a higher-energy alpha than Th-230, and thus will be detected with a higher efficiency than will Th-230. As a result of this sample, MSR determined a correction factor which has been used for subsequent samples spiked with Th-230. It should be noted that the grand average of all participants for this attribute was $17.09 \mathrm{pCi} /$ liter, indicating that there may have also been an EPA sample preparation problem as well.

6. This EPA sample was spiked with Ru-106 at a level where counting errors alone are approximetaly $\pm 50 \%$. BettisPittsburgh believes that falling outside the $\pm 3 \sigma$ limit $( \pm 30 \%)$ for this particular nuclide therefore does not indicate an analytical problem.

7.

The "known value" reported by the EPA for the air filter study is the sum of the Cs-137 value and twice the Sr-90 value, whereas the value reported by Bettis-Pittsburgh is that value as measured using standard analytical methods. A high bias is therefore expected, since the $\mathrm{Y}-90$ daughter of $\mathrm{Sr}-90$ is measured with a higher efficiency than Cs-137 and Sr-90 due to its more energetic beta particle. 
APPENDIX B

Appendix B

\section{USDOE Cross Check Results - CY 1993}

\begin{tabular}{|c|c|c|c|c|c|}
\hline DATE & ATTRIBUTE & $\begin{array}{l}\text { REPORTED } \\
\text { VALUE(1) }\end{array}$ & $\begin{array}{l}\text { KNOWN } \\
\text { VALUE }\end{array}$ & $\underline{\text { Units }^{(3)}}$ & $\underline{N D\left(X_{\sigma}\right)^{(2)}}$ \\
\hline \multirow[t]{8}{*}{ 9303-Air Filter } & $\mathrm{Be7}$ & 26.0 & $27.4 \pm 2.7$ & $\mathrm{~Bq} /$ filter & -0.52 \\
\hline & Mn54 & 11.6 & $11.7 \pm 1.2$ & & -0.08 \\
\hline & Co57 & 2.18 & $2.71 \pm 0.27$ & & -1.96 \\
\hline & Co60 & 1.55 & $1.70 \pm 0.17$ & & -0.88 \\
\hline & Cs134 & 1.89 & $1.96 \pm 0.20$ & & -0.35 \\
\hline & Cs137 & 2.92 & $3.07 \pm 0.31$ & & -0.48 \\
\hline & Ce144 & 14.0 & $19.3 \pm 1.9$ & & -2.79 \\
\hline & Srgo & 0.17 & $0.152 \pm 0.015$ & & 1.20 \\
\hline \multirow[t]{2}{*}{ 9303-Soil } & Sr9o & 32.6 & $41.7 \pm 0.42$ & $\mathrm{~Bq} / \mathrm{Kg}$ & -2.17 \\
\hline & Cs137 & 866 & $923 \pm 92$ & & -0.62 \\
\hline 9303-Vegetation & Cs137 & 20.0 & $24.6 \pm 2.5$ & $\mathrm{~Bq} / \mathrm{Kg}$ & -1.84 \\
\hline \multirow[t]{6}{*}{ 9303-Water } & Mn54 & 108 & $105 \pm 11$ & $\mathrm{~Bq} /$ liter & 0.27 \\
\hline & $\mathrm{Co} 60$ & 48.5 & $45.3 \pm 4.6$ & & 0.70 \\
\hline & Sr9o & 10.0 & $10.3 \pm 1.0$ & & -0.30 \\
\hline & Cs134 & 48.1 & $42.4 \pm 4.2$ & & 1.36 \\
\hline & Cs137 & 55.1 & $50.8 \pm 5.1$ & & 0.84 \\
\hline & Ce144 & 191 & $189 \pm 19$ & & 0.11 \\
\hline \multirow[t]{9}{*}{ 9309-Air Filter } & $U$ & 0.140 & $0.137 \pm 0.14$ & $\mathrm{~Bq} /$ filter & 0.22 \\
\hline & Pu238 & 0.146 & $0.129 \pm 0.13$ & & 1.32 \\
\hline & Pu239 & 0.102 & $0.080 \pm 0.008$ & & 2.75 \\
\hline & Mn54 & 14.7 & $15.4 \pm 1.5$ & & -0.45 \\
\hline & Co57 & 13.3 & $17.3 \pm 1.7$ & & -2.31 \\
\hline & Co60 & 19.2 & $20.5 \pm 2.1$ & & -0.63 \\
\hline & Cs134 & 10.9 & $12.2 \pm 1.2$ & & -1.07 \\
\hline & Cs137 & 16.7 & $18.8 \pm 1.9$ & & -1.12 \\
\hline & Ce144 & 30.9 & $40.3 \pm 4.0$ & & -2.33 \\
\hline \multirow[t]{2}{*}{ 9309-Soil } & Sr90 & 5.56 & $5.40 \pm 0.54$ & $\mathrm{~Bq} / \mathrm{Kg}$ & 0.30 \\
\hline & Cs137 & 9.81 & $11.4 \pm 1.14$ & & -1.39 \\
\hline \multirow[t]{2}{*}{ 9309-Vegetation } & Cs137 & 72.2 & $89.2 \pm 8.9$ & $\mathrm{~Bq} / \mathrm{Kg}$ & -1.91 \\
\hline & Co60 & 5.80 & $6.45 \pm 0.65$ & & -1.01 \\
\hline \multirow[t]{6}{*}{ 9309-Water } & Srgo & 2.63 & $2.52 \pm 0.25$ & $\mathrm{~Bq} /$ liter & 0.44 \\
\hline & Mn54 & 117 & $109 \pm 10.9$ & & 0.73 \\
\hline & Co60 & 110 & $99.6 \pm 10$ & & 1.04 \\
\hline & Cs134 & 59.2 & $56.1 \pm 5.6$ & & 0.55 \\
\hline & Cs137 & 79.9 & $75.5 \pm 7.6$ & & 0.58 \\
\hline & Ce144 & 174 & $173 \pm 17.3$ & & 0.06 \\
\hline
\end{tabular}

\section{Notes:}

1. The reported value is the result of a single determination.

2. Normalized deviation from the known value as described in EML-454 dated May 1, 1986.

3. One Becquerel $(\mathrm{Bq})=27$ picocuries $(\mathrm{pCi})=2.7 \times 10^{-5}$ microcuries $(\mu \mathrm{Ci})$. 


\section{TABLE 1}

FIRST SEMIANNUAL SURFACE WATER QUALITY CONTROL DATA - CY1993

\begin{tabular}{|c|c|c|c|}
\hline Parameter & $\begin{array}{c}\text { Vendor Results } \\
(\mathrm{mg} / \mathrm{l})\end{array}$ & $\begin{array}{c}\text { True Value } \\
(\mathrm{mg} / \mathrm{l})\end{array}$ & $\begin{array}{c}\text { Acceptance Range } \\
(\mathrm{mg} / \mathrm{l})\end{array}$ \\
\hline Alkalinity & 264 & 255 & $235-275$ \\
\hline Aluminum(1) & 122 & 99.8 & $85.3-156.9$ \\
\hline Ammonia $^{(2)}$ & 11.7 & 9.78 & $8.2-11$ \\
\hline Ammonia & 2.0 & 2.0 & $1.66-2.30$ \\
\hline Ammonia & 2.0 & 2.0 & $1.66-2.30$ \\
\hline Biochemical Oxygen Demand & 39 & 41.4 & $30-52$ \\
\hline Chloride & 263 & 254 & $236-272$ \\
\hline Fluoride(2) & 12 & 10 & $9-11$ \\
\hline Fluoride & 1.8 & 1.8 & $1.65-1.94$ \\
\hline Fluoride & 1.8 & 1.8 & $1.65-1.94$ \\
\hline Hardness & 321 & 318 & $273-362$ \\
\hline Iron (1) & 59 & 49.9 & $37.3-64.5$ \\
\hline Manganese $e^{(1)}$ & 11.0 & 10.0 & $5.26-13.38$ \\
\hline Nitrate & 13.1 & 13.8 & $12-16$ \\
\hline Oil \& Grease ${ }^{(1)}$ & 55 & 49 & $37-61$ \\
\hline Oil \& Grease ${ }^{(1)}$ & 35 & 37 & $28-46$ \\
\hline Oil \& Grease (1) & 47 & 49 & $37-61$ \\
\hline Oil \& Grease $e^{(1)}$ & 46 & 49 & $37-61$ \\
\hline Oil \& Grease & 18 & 20 & $12.0-24.0$ \\
\hline Oil \& Grease ${ }^{(1)}$ & 48 & 49 & $37-61$ \\
\hline Oil \& Grease ${ }^{(1)}$ & 45 & 49 & $37-61$ \\
\hline $\mathrm{pH}^{(1)}$ & 9.1 & 9.0 & $8.8-9.2$ \\
\hline $\mathrm{pH}^{(1)}$ & 9.1 & 9.0 & $8.8-9.2$ \\
\hline $\mathrm{pH}^{(1)(3)}$ & 9.0 & 9.0 & $8.8-9.2$ \\
\hline $\mathrm{pH}^{(1)}$ & 6.0 & 6.0 & $5.90-6.08$ \\
\hline $\mathrm{pH}^{(1)}$ & 8.9 & 9.1 & $8.9-9.3$ \\
\hline Phenol & 0.19 & 0.20 & $0.15-0.25$ \\
\hline Sulfate & 237 & 256 & $220-292$ \\
\hline Suspended Solids & 25 & 22.8 & $19-27$ \\
\hline Suspended Solids & 23 & 22.8 & $19-27$ \\
\hline Suspended Solids & 27 & 22.8 & $19-27$ \\
\hline Suspended Solids & 30 & 31.8 & $28.1-35.2$ \\
\hline Suspended Solids & 48 & 41.5 & $34-50$ \\
\hline Suspended Solids & 102 & 99.1 & $79-119$ \\
\hline Total Dissolved Solids & 1070 & 1060 & $956-1170$ \\
\hline Turbidity (1) & 4.3 & 4.27 & $3.77-5.01$ \\
\hline
\end{tabular}

(1) Units are $\mu \mathrm{g} / \mathrm{l}$ for aluminum, iron, and manganese; $\mathrm{mg} /$ bottle for oil and grease; $\mathrm{pH}$ units for $\mathrm{pH}$; and nephelometric turbidity units (NTU) for turbidity.

(2) Vendor results not within acceptable range. All internal quality control conducted in conjunction with the analysis of the sample was reviewed, and it was determined that the high value may have been caused by improper volumetric preparation of the solution for analysis. The vendor resolved this problem and additional samples (see next sample results in Table) were submitted for analysis, and the results were within the acceptable range.

(3) The same analysis results were obtained for seven additional quality control samples for $\mathrm{pH}$. 


\section{TABLE 2}

SECOND SEMIANNUAL SURFACE WATER QUALITY CONTROL DATA - CY1993

\begin{tabular}{|c|c|c|c|}
\hline Parameter & $\begin{array}{c}\text { Vendor Results } \\
(\mathrm{mg} / \mathrm{l})\end{array}$ & $\begin{array}{c}\text { True Value } \\
\text { (mg/l) }\end{array}$ & $\begin{array}{c}\text { Acceptance Range } \\
(\mathrm{mg} / \mathrm{l})\end{array}$ \\
\hline $\begin{array}{l}\text { Acid Compounds } \\
\text { a-cresol } \\
\text { m-cresol \& p-cresol } \\
\text { 2,4,6-trichlorophenol } \\
\text { 2,4,5-trichlorophenol } \\
\text { pentachlorophenol }\end{array}$ & $\begin{array}{c}903 \\
1720 \\
712 \\
753 \\
582\end{array}$ & $\begin{array}{l}1000 \\
2000 \\
1000 \\
1000 \\
1000\end{array}$ & $\begin{array}{c}400-1000 \\
1000-2000 \\
600-1200 \\
500-1300 \\
600-1200\end{array}$ \\
\hline Alkalinity & 24 & 24.2 & $21.5-27.4$ \\
\hline Aluminum(1) & 512 & 450 & $370-530$ \\
\hline Ammonia & 2.0 & 2.0 & $1.66-2.30$ \\
\hline Antimony ${ }^{(1)}$ & 101 & 105 & $73-131$ \\
\hline Arsenic $^{(1)}$ & 127 & 125 & $94-150$ \\
\hline $\begin{array}{l}\text { Base Neutral Compounds } \\
\text { 1,4-dichlorobenzene } \\
\text { hexachloroethane } \\
\text { nitrobenzene } \\
\text { hexachlorobutadiene } \\
\text { 2,4-dinitrotoluene } \\
\text { hexachlorobenzene }\end{array}$ & $\begin{array}{c}893 \\
826 \\
1120 \\
779 \\
681 \\
1070\end{array}$ & $\begin{array}{l}1000 \\
1000 \\
1000 \\
1000 \\
1000 \\
1000\end{array}$ & $\begin{array}{l}500-1000 \\
500-1100 \\
600-1300 \\
450-1050 \\
450-1000 \\
500-1100\end{array}$ \\
\hline Beryllium $^{(1)}$ & 96 & 101 & $83-119$ \\
\hline Biochemical Oxygen Demand & 47.5 & 41.4 & $30-52$ \\
\hline Cadmium $^{(1)}$ & 93 & 91.3 & $74-108$ \\
\hline Chloride ${ }^{(2)}$ & 44 & 51.4 & $48-55.4$ \\
\hline Chloride ${ }^{(2)}$ & 43 & 52.1 & $48.2-55.4$ \\
\hline Chloride ${ }^{(2)}$ & 46 & 52.1 & $48.2-55.4$ \\
\hline Chloride ${ }^{(2)}$ & 56 & 70 & $63-77$ \\
\hline Chloride ${ }^{(2)}$ & 2.0 & 4.0 & $3.6-4.4$ \\
\hline Chloride & 97 & 100 & $90-110$ \\
\hline Chloride & $<1.0$ & 1.0 & $0.9-1.1$ \\
\hline Chromium $^{(1)}$ & 668 & 650 & $533-767$ \\
\hline Copper ${ }^{(1)}$ & 169 & 159 & $130-202$ \\
\hline Fluoride & 1.0 & 1.0 & $0.9-1.08$ \\
\hline Hardness & 72 & 70.5 & $64.9-75.5$ \\
\hline Hardness & 320 & 318 & $273-362$ \\
\hline $\operatorname{Iron}^{(1)}$ & 544 & 525 & $430-620$ \\
\hline Lead $^{(1)}$ & 167 & 145 & $116-174$ \\
\hline Manganese $^{(1)}$ & 101 & 101 & $83-119$ \\
\hline Mercury ${ }^{(1)}$ & 3.3 & 3.25 & $2.2-4.1$ \\
\hline Nickel $^{(1)}$ & 165 & 163 & $130-196$ \\
\hline Nitrate & 1.79 & 2.0 & $1.71-2.27$ \\
\hline
\end{tabular}


TABLE 2 (Continued)

\begin{tabular}{|c|c|c|c|}
\hline Parameter & $\begin{array}{c}\text { Vendor Results } \\
(\mathrm{mg} / \mathrm{l})\end{array}$ & $\begin{array}{l}\text { True Value } \\
\text { (mg/l) }\end{array}$ & $\begin{array}{c}\text { Acceptance Range } \\
(\mathrm{mg} / \mathrm{l})\end{array}$ \\
\hline Oil \& Grease & 38 & 45 & $33-56$ \\
\hline Oil \& Grease $\theta^{(3)}$ & 37 & 45 & $33-56$ \\
\hline Oil \& Grease ${ }^{(3)}$ & 39 & 45 & $33-56$ \\
\hline Oil \& Grease & 17.3 & 20 & $12.0-24.0$ \\
\hline Oil \& Grease ${ }^{(3)}$ & 37 & 45 & $33-56$ \\
\hline Oil \& Grease & 18 & 20 & $12.0-24.0$ \\
\hline $\begin{array}{l}\text { Pesticides }^{(1)} \\
\text { aldrin } \\
\text { chlordane } \\
4,4^{\prime}-\mathrm{DDD} \\
4,4^{\prime}-\mathrm{DDE} \\
4,4^{\prime}-\mathrm{DDT} \\
\text { dieldrin } \\
\text { endosulfan } \\
{ }^{(4)} \\
\text { heptachlor } \\
\text { heptachlor epoxide } \\
\text { methoxychlor } \\
\end{array}$ & $\begin{array}{c}0.82 \\
2.4 \\
1.5 \\
2.96 \\
0.97 \\
0.54 \\
<0.05 \\
0.53 \\
0.58 \\
5.4 \\
\end{array}$ & $\begin{array}{c}1.64 \\
4.13 \\
1.60 \\
3.20 \\
1.10 \\
0.852 \\
0.769 \\
1.11 \\
0.526 \\
5.09\end{array}$ & $\begin{array}{c}0.69-2.0 \\
1.9-4.9 \\
0.50-2.3 \\
0.96-4.6 \\
0.27-1.8 \\
0.31-1.2 \\
0.32-1.2 \\
0.38-1.2 \\
0.19-0.75 \\
1.9-8.0\end{array}$ \\
\hline $\mathrm{pH}^{(3)(5)}$ & 9.0 & 9.0 & $8.8-9.2$ \\
\hline $\mathrm{pH}^{(3)}$ & 6.1 & 6.0 & $5.90-6.08$ \\
\hline Phenol & 0.23 & 0.228 & $0.17-0.28$ \\
\hline Polychlorinated Biphenyls ${ }^{(1)}$ & 2.6 & 2.53 & $0.41-3.2$ \\
\hline Selenium ${ }^{(1)}$ & 124 & 119 & $89-150$ \\
\hline Silver ${ }^{(1)}$ & 101 & 95.4 & $78-113$ \\
\hline Sulfate & 20 & 20 & $16.9-22.6$ \\
\hline Suspended Solids & 42 & 41.5 & $34-50$ \\
\hline Suspended Solids & 41 & 41.5 & $34-50$ \\
\hline Suspended Solids & 47 & 41.5 & $34-50$ \\
\hline Suspended Solids & 280 & 279 & $251-285$ \\
\hline Suspended Solids & 85 & 87.4 & $74-101$ \\
\hline Suspended Solids & 85 & 87.4 & $74-101$ \\
\hline Thallium $^{(1)}$ & 89 & 85.8 & $56-112$ \\
\hline Total Dissolved Solids & 1000 & 1060 & $956-1170$ \\
\hline Total Dissolved Solids & 130 & 153 & $118-194$ \\
\hline Turbidity $^{(3)}$ & 2.8 & 2.5 & $2.1-2.9$ \\
\hline
\end{tabular}


Appendix C

APPENDIX C

Page 4 of 4

TABLE 2 (Continued)

\begin{tabular}{|c|c|c|c|}
\hline Parameter & $\begin{array}{c}\text { Vendor Results } \\
\text { (mg/l) }\end{array}$ & $\begin{array}{c}\text { True Value } \\
\text { (mg/l) }\end{array}$ & $\begin{array}{c}\text { Acceptance Range } \\
(\mathrm{mg} / \mathrm{l})\end{array}$ \\
\hline $\begin{array}{l}\text { Volatile Organic Compounds }{ }^{(1)} \\
\text { benzene } \\
\text { bromodichloromethane } \\
\text { bromoform } \\
\text { bromomethane } \\
\text { carbon tetrachloride } \\
\text { chlorobenzene } \\
\text { chloroethane } \\
\text { chloroform } \\
\text { chromomethane } \\
\text { dibromochloromethane } \\
\text { 1,2-dichlorobenzene } \\
\text { 1,3-dichlorobenzene } \\
\text { 1,4-dichlorobenzene } \\
\text { 1,1-dichloroethane } \\
\text { 1,2-dichloroethane } \\
\text { 1,1-dichloroethene } \\
\text { trans-1,2-dichloroethene } \\
\text { 1,2-dichloropropane } \\
\text { cis-1,3-dichloropropene } \\
\text { trans-1,3-dichloropropene } \\
\text { ethylbenzene } \\
\text { methylene chloride } \\
\text { 1,1,2,2-tetrachloroethane } \\
\text { tetrachloroethene } \\
\text { toluene } \\
\text { 1,1,1-trichloroethane } \\
\text { 1,1,2-trichloroethane } \\
\text { trichloroethene } \\
\text { trichlorofluoromethane } \\
\text { vinyl chloride }\end{array}$ & $\begin{array}{l}20 \\
22 \\
20 \\
20 \\
20 \\
19 \\
20 \\
22 \\
22 \\
20 \\
18 \\
17 \\
17 \\
18 \\
19 \\
18 \\
19 \\
19 \\
18 \\
19 \\
18 \\
22 \\
20 \\
19 \\
20 \\
20 \\
21 \\
19 \\
17 \\
18\end{array}$ & $\begin{array}{c}20.06 \\
20.02 \\
20.02 \\
20.06 \\
20.02 \\
20.0 \\
20.04 \\
20.02 \\
20.06 \\
20.02 \\
20.02 \\
20.0 \\
20.02 \\
20.02 \\
20.02 \\
20.04 \\
20.02 \\
20.02 \\
20.0 \\
20.0 \\
20.08 \\
20.02 \\
20.02 \\
20.02 \\
20.06 \\
20.02 \\
20.04 \\
20.02 \\
20.0 \\
20.04\end{array}$ & $\begin{array}{l}12-28 \\
14-26 \\
12-28 \\
10-30 \\
14-26 \\
14-26 \\
12-28 \\
14-26 \\
10-30 \\
12-28 \\
14-26 \\
14-26 \\
14-26 \\
12-26 \\
14-26 \\
12-28 \\
10-30 \\
14-26 \\
12-28 \\
12-28 \\
14-26 \\
12-28 \\
14-26 \\
12-28 \\
14-26 \\
10-28 \\
14-26 \\
14-26 \\
12-28 \\
12-28\end{array}$ \\
\hline
\end{tabular}

(1) Units are $\mu \mathrm{g} / \mathrm{l}$.

(2) Vendor results not within acceptable range. All internal quality control conducted in conjunction with the analysis of the sample was reviewed, and it was determined that the low value may have been caused by the improper standardization of the mercuric nitrate titrant used to perform the analysis. The vendor resolved this problem and additional samples (see next sample results in Table) were submitted for analysis, and the results were within the acceptable range.

(3) Units are $\mathrm{mg} / \mathrm{bottle}$ for oil and grease; $\mathrm{pH}$ units for $\mathrm{pH}$; and neophelometric turbidity units (NTU) for turbidity.

(4) Vendor results not within acceptable range. All internal quality control conducted in conjunction with the analysis of the sample was reviewed, and it was determined that the high value may have been caused by chlordane masking the sample. Even though this effect occurred for the quality control sample, it is not considered significant for the environmental monitoring program since neither chlordane nor endosulfan were detected in any of the influent or effluent samples.

(5) The same analysis results were obtained for ten additional quality control samples for $\mathrm{pH}$. 


\section{APPENDIX D \\ ENVIRONMENTAL PERMITS}

Air Operating Permits

Unit

H-62148, H-62149

$\mathrm{H}-7157^{\text {** }}$

C-1093

$\mathrm{H}-3132, \mathrm{H}-3133$

$\mathrm{H}-211500, \mathrm{H}-211510$

H-211520, H-211530

Installation Permits

Heat Source E

Vapor Extraction Pilot Test

Water Pollution Permits

Bull Run Outfall 001

Northeast Area Outfall 002

Stormwater Outfall 003

Stormwater Outfall 004

Resource Conservation and Recovery Act

Chemical/Hazardous Waste

Storage Building
ALLEGHENY COUNTY

Permit Number

Renewal Date

703253100000512 January 1995

703253100000511

703253100000509 January 1995

$703253100000901 \quad$ January 1995

$703253100000600 \quad$ January 1995

92-1-0001-C

93-1-0004-P

NPDES Permit Number Renewal Date

PA0000914

July 24, 1992*
The RCRA Part B permit application was submitted to the PA Dept. of Environmental Resources and the U.S. Environmental Protection Agency on November 7, 1988.

Bettis currently manages hazardous waste in accordance with a Part A permit consistent with Pennsylvania requirements for interim status.

* Renewal application submitted to Pennsylvania Department of Environmental Resources on January 24, 1992.

** Terminated operation November 15, 1993 


\section{APPENDIX E}

\section{LIST OF ACRONYMNS}

ACHD

Administrative Order on Consent

ARAC

$B L$

BNA

CERCLA

DCE

DOE

DOT

EP

EPA

IWS

MDL

NPDES

NRC

PA-DER

PAH

PCB

PCE

PES

RA

RCRA

RFI

RME

TCA

TCLP

TSD

VOC

WWSC
Allegheny County Health Department

Consent Order

Atmospheric Release Advisory Capability

Bettis Landfill

Base/Neutral and Acids

Comprehensive Environmental Response, Compensation and Liability Act

Dichloroethylene

U.S. Department of Energy

U.S. Department of Transportation

Extraction Toxicity Procedure

U.S. Environmental Protection Agency

Inactive Waste Site

Minimum Detection Limit

National Pollutant Discharge Elimination System

Nuclear Regulatory Commission

Pennsylvania Department of Environmental Resources

Polyaromatic Hydrocarbon

Polychlorinated Biphenyls

Tetrachloroethylene

Pesticides

Risk Assessment

Resource Conservation and Recovery Act

RCRA Facility Investigation

Reasonable Maximum Exposure

1,1,1-Trichloroethane

Toxicity Characteristic Leaching Procedure

Treatment/Storage/Disposal

Volatile Organic Compound

Valley Welding Supply Company 